Leston, L. F. V., and N. Koper. 2017. Managing urban and rural rights-of-way as potential habitats for grassland birds. Avian Conservation and Ecology 12(2):4. https://doi.org/10.5751/ACE-01049-120204

Copyright (C) 2017 by the author(s). Published here under license by the Resilience Alliance.

Research Paper

\title{
Managing urban and rural rights-of-way as potential habitats for grassland birds
}

\author{
Lionel F. V. Leston ${ }^{1}$ and Nicola Koper ${ }^{2}$ \\ ${ }^{1}$ Department of Biological Sciences, University of Alberta, ${ }^{2}$ University of Manitoba
}

\begin{abstract}
Urban grassy rights-of-way (ROWs) such as along transmission lines could be managed cumulatively as collections of potential grassland habitats to contribute to the conservation of grassland birds. To optimize conservation opportunities, managing urban ROWs for grassland birds may require reductions in frequent mowing and spraying and may also depend on the suitability of landscape structure within the urban environment. We compared effects of mowing regime relative to effects of the matrix surrounding ROWs on grassland bird abundance and occupancy along 48 ROWs in and surrounding Winnipeg, Manitoba, in 2007-2009. We used both hierarchical distance-sampling and multiseason occupancy modeling methods to account for effects of urbanization (e.g., traffic noise), observer experience, time of season, and survey time in the morning on the probability of detecting birds at study sites. We did not find differences in detection of grassland birds due to urbanization, but we did find effects of time of season, survey time in the morning, and observer experience. After accounting for availability, we found that several species declined along ROWs that were surrounded by more urban or wooded land. Western Meadowlark occupancy increased as the amount of grassland within $100 \mathrm{~m}$ of ROWs increased. Savannah Sparrow showed some evidence of increasing with mowing, whereas Clay-colored Sparrow showed some evidence of decreasing with mowing, although these species and Western Meadowlark also increased within hayed ROWs. We conclude that urban ROWs managed as grassland bird habitats will probably attract more individuals and species if there is less nearby urban or wooded land and more grassland, and within which there is a mixture of unmowed and hayed ROW sections.
\end{abstract}

\section{Aménagement d'emprises en milieu urbain et rural comme habitat potentiel d'oiseaux champêtres}

RÉSUMÉ. Les emprises herbeuses en milieu urbain, telles que celles des lignes de transport d'électricité, pourraient être cumulativement aménagées en un ensemble de milieux de prairie potentiels afin de contribuer à la conservation des oiseaux champêtres. En vue d'optimiser les occasions de conservation, l'aménagement des emprises urbaines pour ces oiseaux pourrait nécessiter une diminution de la fréquence du fauchage et de l'épandage, et pourrait aussi dépendre du caractère propice de la structure de paysage dans l'environnement urbain. Nous avons comparé les effets du régime de fauchage en fonction des effets de la matrice environnant les emprises sur l'occurrence et l'abondance d'oiseaux champêtres le long de 48 emprises situées à Winnipeg et ses environs, au Manitoba, en 2007-2009. Afin de prendre en compte les effets de l'urbanisation (p. ex. bruit de la circulation), de l'expérience de l'observateur, du moment dans la saison et de l'heure de l'inventaire sur la probabilité de détecter les oiseaux aux sites d'étude, nous avons utilisé deux méthodes de modélisation : à partir de l'échantillonnage par distance hiérarchique et de la présence multisaisonnière. Nous n'avons pas trouvé de différence dans la détection des oiseaux champêtres par rapport au degré d'urbanisation, mais nous avons trouvé que le moment dans la saison, l'heure de l'inventaire et l'expérience de l'observateur avaient des effets. Une fois la disponibilité prise en compte, nous avons trouvé que la présence de plusieurs espèces a diminué le long des emprises qui étaient bordées de milieux urbains ou forestiers. L'augmentation de la présence de la Sturnelle de l'Ouest suivait celle de la quantité de prairies dans un rayon de $100 \mathrm{~m}$ des emprises. La présence du Bruant des prés semblait augmenter avec le fauchage, tandis que celle du Bruant des plaines semblait diminuer, quoique la présence de ces deux espèces et de la sturnelle a aussi augmenté dans les emprises de foin. Nous concluons que les emprises en milieu urbain aménagées comme habitat d'oiseaux champêtres attireront sans doute plus d'individus et d'espèces s'il y a moins de milieux urbain et forestier environnants, au profit de davantage de prairies, et si elles présentent un mélange de sections non fauchées et de foin.

Key Words: grassland birds; hierarchical distance sampling; mowing; multiseason occupancy models; rights-of-way; urbanization

\section{INTRODUCTION}

Urban landscapes are increasing in extent and need to be managed so that they sustain or enhance biodiversity and wildlife habitats (Young 2000, Hansen et al. 2005, McDonald et al. 2008). Current typical land management protocols may not achieve these goals. For example, urban rights-of-way (ROWs; e.g., transmission lines for distributing electricity, highways, other roadsides) are usually intensively mowed and sprayed with herbicides to create tidy open areas free of weeds and litter, to reduce standing vegetation as a potential fire hazard near properties, and to reduce plants releasing wind-borne pollen as a source of human allergens (Byrne 2005, Zimdahl 2007). Frequent mowing of urban ROWs makes such spaces less habitable for many species of wildlife, e.g., tall plant species (Fenner and Palmer 1988, Schippers and Joenje 2002, Hovd 
and Skogen 2005), broadleaf plants (Parr and Way 1988), shelter habitat for butterflies and other arthropods (Swengel 2001, Kruess and Tscharntke 2002), and nests of ground-nesting birds (Kershner and Bollinger 1996). If management protocols were altered to make urban ROWs more wildlife friendly, they could potentially create extensive habitat for wildlife. For example, Manitoba Hydro mows and sprays $~ 360$ ha of transmission lines in Winnipeg, Manitoba alone (equivalent to a $100-\mathrm{m}$ strip of habitat $36 \mathrm{~km}$ long; Manitoba Hydro, unpublished data) to control weeds and create homogeneous green spaces. In addition to transmission lines in other cities, there are thousands of kilometers of roadside ROWs in the North American Midwest that could be managed in a similar manner for wildlife (Morgan et al. 1995, Ries et al. 2001).

North American grassland birds, which, as a group, have experienced recent continental population declines (Herkert 1994, Peterjohn and Sauer 1999), might benefit from changes to vegetation management along urban ROWs. Although these declines have largely been attributed to the conversion of grasslands to agriculture followed by the large-scale intensification and homogenization of agricultural environments (Herkert 1994, Peterjohn and Sauer 1999), grassland birds have also been observed to respond negatively to urbanization (Bock et al. 1999, Engle et al. 1999, Haire et al. 2000) and increases in wooded lands (Bakker et al. 2002). One reason for this trend might be the intensive vegetation management regimes that are common within urban grasslands. Reducing frequent mowing and spraying along urban ROWs could enable these ROWs to support more species of plants (Parr and Way 1988, Munguira and Thomas 1992, Leston and Koper 2016), which in turn could support more arthropods (Morris and Rispin 1988, Swengel 2001, Kruess and Tscharntke 2002) and thus provide food resources for grassland birds. Reducing mowing along urban ROWs may also reduce the destruction of bird nests (Kershner and Bollinger 1996) and increase the availability of nesting sites for ground-nesting birds that prefer tall vegetation (e.g., Clay-colored Sparrow, Spizella pallida [Knapton 1994]; Le Conte's Sparrow, Ammodramus lecontei [Lowther 2005]; Sedge Wren, Cistothorus platensis [Murray and Best 2003, Roth et al. 2005]). However, reducing the intensity of vegetation management might not benefit all grassland songbirds. Mowing might improve habitat for herbivorous arthropod prey for birds (Seastedt 1985, Morris and Rispin 1988) or create nesting sites for ground-nesting birds preferring short vegetation (e.g., Grasshopper Sparrow, Ammodramus savannarum; Savannah Sparrow Passerculus sandwichensis; Murray and Best 2003, Roth et al. 2005). Therefore, quantifying the effects of mowing on grassland songbirds is necessary prior to suggesting any changes to the management of urban ROWs.

Further, the extent to which management activities would effectively contribute to conservation may vary with landscape structure. In addition to more frequent mowing, grassland habitats along urban ROWs are potentially exposed to numerous other anthropogenic disturbances such as pollution, noise, and exotic weeds that thrive in disturbed environments. Edge effects, habitat fragmentation, and isolation of remnant habitats are some mechanisms that may render urban wildlife habitats less attractive, less hospitable, or less accessible to organisms (e.g., McKinney 2002, Ingelfinger and Anderson 2004, Blickley and
Patricelli 2010). Because urban ROWs are managed differently and are exposed to different threats compared with rural sites, it can be difficult to distinguish effects of urbanization from effects of vegetation management. This is problematic because if apparent negative effects of mowing and herbicide application are driven by other factors associated with urbanization, then changing vegetation management along urban ROWs would neither improve habitat for grassland birds nor result in increased settlement by grassland birds. Disentangling effects of the urban landscape from effects of vegetation management within it requires manipulative experiments to remove this correlation.

An additional issue for bird studies along urban gradients is that most bird detections during surveys are aural. The probabilities of detecting birds are likely to vary among sites (Anderson 2001) because relatively urban sites may be exposed to higher noise levels due to urban traffic noise (iTrans Consulting 2009), possibly reducing detection rates of birds at urban sites (Ingelfinger and Anderson 2004, Blickley and Patricelli 2012, Lituma and Buehler 2016). Therefore, apparent declines of birds with increasing urbanization might not reflect actual decreases in bird numbers, but declining perceptibility of birds. Given that the probability of detecting singing birds often declines within surveys with increasing distance between singing birds and observers (Buckland et al. 2005), increasing urban noise might reduce the probability that individual birds are detected at noisy urban sites. The probability of detecting birds may also vary among sites because of rates of vocalization by birds, which can vary with time of season and time of day when surveys are conducted (Farnsworth et al. 2002). Thus, urban ecologists require modeling techniques that can calculate the separate effects of habitat features on: (1) the probability that birds are present at sites, $\mathrm{P}_{\mathrm{P}}$; (2) the probability that birds are vocalizing and therefore are available to be detected at sites where they are present, $\mathrm{P}_{\mathrm{A}}$; and (3) the perceptibility of birds, $P_{D}$, i.e., the probability of detecting birds given their presence and availability for detection at sites. The perceptibility of birds potentially varies with the distance of individual birds from the observer, and this distance relationship can be specified. Hierarchical distance-sampling methods for estimating bird densities can account for all three of these probabilities because these methods treat detection during a site visit as a product of three separate functions, one each for $\mathrm{P}_{\mathrm{P}}, \mathrm{P}_{\mathrm{A}}$, and $\mathrm{P}_{\mathrm{D}}$. However, these models are subject to the assumption of population closure, meaning that such methods can only be applied to repeated surveys within the same season (Sillett et al. 2012).

In contrast, multiseason occupancy models enable observers to account for how the presence of birds at sites is affected by immigration or emigration between breeding seasons (MacKenzie et al. 2003, Kéry and Chandler 2016). Multiseason occupancy models could identify responses by birds (changes in habitat settlement between breeding seasons) to changes in vegetation at particular sites between years such as a short-term change in vegetation management. However, all occupancy models can only be used to predict presence or absence of birds at sites instead of abundance, they do not incorporate distancesampling methods, and they do not permit separate estimation of $\mathrm{P}_{\mathrm{A}}$ and $\mathrm{P}_{\mathrm{D}}$ (because estimates of $\mathrm{P}_{\mathrm{D}}$ require distance-sampling and measures of bird abundance at sites). Nevertheless, hierarchical distance sampling and multiseason occupancy 
models can be used in combination: urban ROWs are usually narrow, linear habitats within which birds using these habitats are never too far from observers along a transect. Within short distances of observers, the detection probability of grassland birds given their availability may not significantly decline even within noisy environments (Koper et al. 2015). If hierarchical distance-sampling methods do not indicate a strong effect of urban noise on the detection of birds within surveys, then multiseason occupancy models can be used to predict the probability of grassland birds using urban ROWs over multiple seasons.

We used hierarchical distance-sampling models and multiseason occupancy models to assess how and where urban ROWs may be managed as habitats for grassland birds by comparing the relative effects of local vegetation features associated with ROW management to effects of surrounding land use. We tested the following five hypotheses. (1) If urban sites are noisier because of greater traffic volume nearby, then the detection probability of birds would decline more rapidly with increasing bird distance from observers at urban sites. (2) If singing rates of individual species vary across visits, and species are "available" to observers that recognize their songs, then the detection probability or availability would be higher for more experienced observers, lower later in the morning, and higher later in the season. (3) If local vegetation preferences explain grassland bird abundance, then species that prefer shrubby or tall vegetation will decrease with mowing, and species that prefer short vegetation will increase with mowing. (4) Given that many grassland birds increase in abundance at landscape scales where there are more grasslands, we predicted that all species would increase and show a higher probability of occupancy at sites with more grassland within 100 m. (5) Finally, given that many grassland birds decline in more wooded or urbanized landscapes, we predicted lower numbers and probabilities of occupancy by species at sites with more wooded land and/or urban land within $100 \mathrm{~m}$.

\section{METHODS}

\section{Study area}

We conducted surveys in and near Winnipeg, Manitoba, Canada (49.90 ${ }^{\circ} \mathrm{N}, 97.14^{\circ} \mathrm{W}$; Fig. 1) over three years (2007-2009) along 48 power transmission line ROW sections with grassy rights-ofway that were at least $30 \mathrm{~m}$ wide and long enough to contain a straight, 500-m transect along which we conducted grassland bird surveys. Dominant land uses surrounding ROWs were urban lands, croplands, wooded lands (aspen forests, shrublands), and grasslands with a mixture of exotic and tallgrass prairie plant species (Leston and Koper 2016). Most ROW sites within Winnipeg's Perimeter Highway $(N=13)$ were mowed and sprayed frequently (i.e., sprayed with 2,4-D herbicide and cut twice a year, with cut vegetation left to decompose on-site). ROW sites outside Winnipeg's Perimeter Highway were usually mowed and sprayed infrequently (i.e., cut once a year without haying, with cut vegetation left to decompose on-site; $N=9$ ), hayed (i.e., cut once a year without spraying, with cut vegetation left to dry and cure before it was baled and removed; $N=7$ ), or unmowed (no vegetation was cut or sprayed except for tree removal; $N=19$ ). All but 3 hayed sites were within $20 \mathrm{~km}$ of Winnipeg, with 21 of the 48 sites within Winnipeg's Perimeter Highway, and the 3 distant hayed sites were within $50 \mathrm{~km}$ (Fig. 1). Survey transects were at least $500 \mathrm{~m}$ apart to minimize the likelihood that bird species had territories spanning study sites. The most abundant grassland birds at the study sites were Clay-colored Sparrow, Le Conte's Sparrow, Savannah Sparrow, and Western Meadowlark (Sturnella neglecta).

Fig. 1. Map of the study area in Manitoba, Canada (top) centered on the city of Winnipeg (bottom). Hollow squares $=$ sites mowed (without haying) twice per year, hollow triangles $=$ sites mowed (without haying) once per year, hollow circles $=$ sites hayed once per year, opaque circles $=$ sites normally left unmowed and unmanaged except for tree removal. Sites within Winnipeg's Perimeter Highway (black outline) had more builtup lands within $100 \mathrm{~m}$ of transects. Sites northeast of the Perimeter Highway had more wooded lands within $100 \mathrm{~m}$ of transects. Sites south, southeast, and west of the Perimeter Highway had more grassland within $100 \mathrm{~m}$ of transects. Map created using ArcGIS (ESRI 2002). Basemap Sources: National Geographic, Environmental Systems Research Institute, DeLorme, HERE, United Nations Environment Programme World Conservation Monitoring Centre, U.S. Geological Survey, National Aeronautics and Space Administration, Ecosystem Services Assessment, Japan Ministry of Economy Trade and Industry, Natural Resources Canada, General Bathymetric Chart of the Oceans, National Oceanic and Atmospheric Administration, and Increment P.

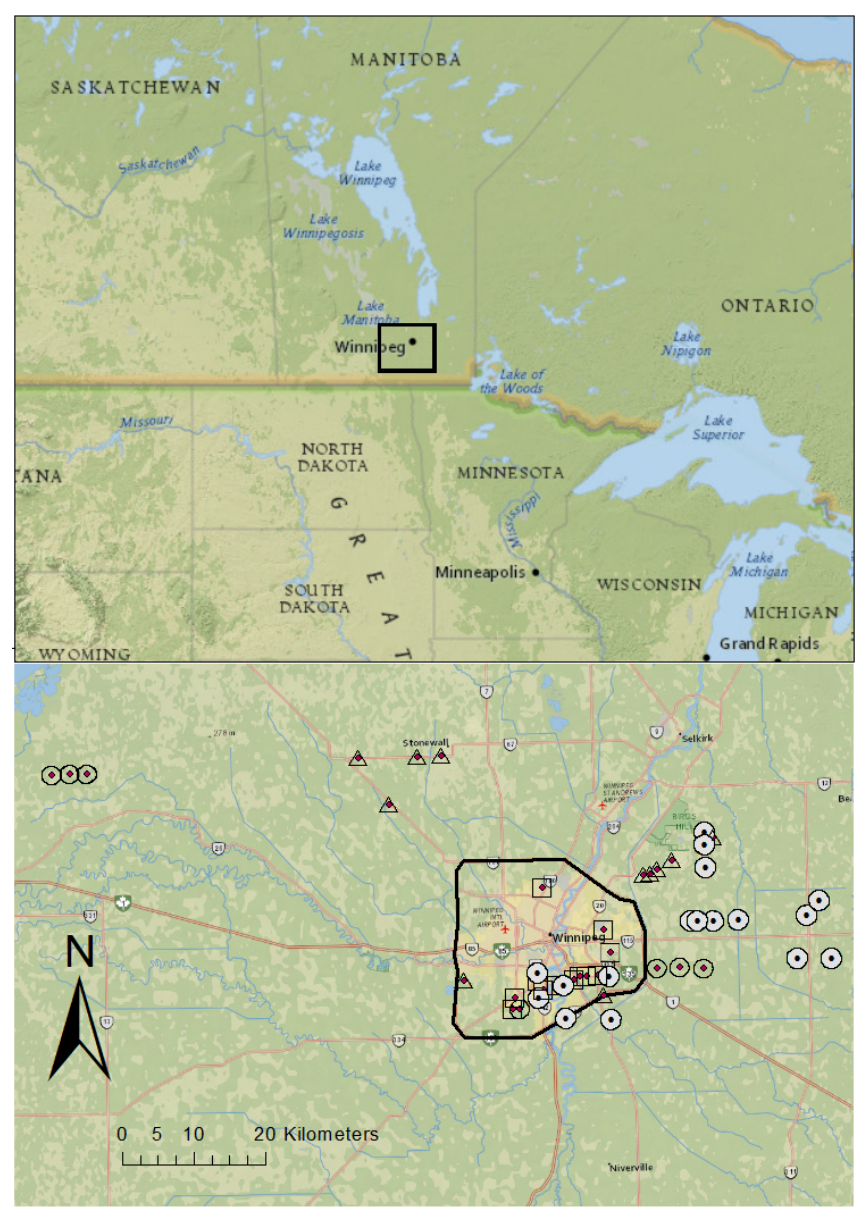




\section{Bird surveys}

We counted the number of individual birds per species within a $50,000-\mathrm{m}^{2}$ area ( $50 \mathrm{~m}$ either side of the $500-\mathrm{m}$ transect) during three rounds of avian transects per site each year (during 25 May30 June), with at least 10 days between visits to the same site. We minimized effects of weather by conducting bird surveys between dawn and 10:00 AM on days without rain or strong winds, and, when feasible, we used different observers on different visits (Bibby et al. 1992). Most observers were 19-23 years old except for one experienced observer who was $<40$ years old by the end of the study.

The probability that birds are perceived $\left(\mathrm{P}_{\mathrm{D}}\right)$ may decline with increasing traffic noise near study sites and with surveys later in the morning because traffic volumes in and near Winnipeg generally increase from when surveys begin at dawn to rush hour (8:00-10:00 AM; iTrans Consulting 2009). We classified the time of surveys in the morning within 1-h periods $(5: 00-6: 00,6: 00$ $7: 00,7: 00-8: 00,8: 00-9: 00$, and 9:00-10:00) based on the frequency distribution of the numbers of vehicles within a 24-h period in 2007 (iTrans Consulting 2009). During bird surveys in 2007, observers also noted the numbers of vehicles they heard passing by study sites along roads parallel or perpendicular to the transmission lines containing each transect as a measure of traffic volume and potential traffic noise masking bird sounds during surveys.

\section{Covariates affecting bird presence at sites}

We used measures of land uses within $100 \mathrm{~m}$ of transects as predictors of abundance of and occupancy by grassland birds, hypothesizing that these land uses affect the amount of habitat and nonhabitat for grassland birds along ROWs. To measure land uses around each 500-m transect, we generated 100-m buffers around each 500-m transect in ArcGIS 8.3 (ESRI 2002), digitized the boundaries of different land uses from overhead digital orthophotos (Manitoba Conservation Map Sales, http://www. gov.mb.ca/sd/canadamapsales/index.html) within $100 \mathrm{~m}$ of each transect, and classified the resulting polygons as urban lands (buildings, roads, concrete), tilled croplands, wooded lands (forests, shrublands), or grasslands (frequently mowed grassy areas such as sports fields, lawns, and rights-of-way; hayed forage croplands; unhayed grasslands that were mowed once a year; pastures; and unmanaged grasslands such as fallow fields and unmowed transmission lines). We ground-truthed our classifications against Google Earth maps, LANDSAT data (Manitoba Conservation Map Sales, http://www.gov.mb.ca/sd/ canadamapsales/index.html), and on-site observations. Grasslands within $100 \mathrm{~m}$ of transects (48 sites in 2007-2008: mean $=45.0 \%$, $\mathrm{SD}=22.5 \%$ ) were either frequently mowed and sprayed twice per year without haying $(N=13)$, mowed and sprayed once a year without haying $(N=9)$, mowed once a year and hayed $(N=7)$, and unmowed except for tree removal $(N=19)$. Urban lands (defined as buildings, roads, and concrete) composed $\geq 18 \%$ of lands within $100 \mathrm{~m}$ of urban site transects within Winnipeg's Perimeter Highway compared with $<8 \%$ of such lands within 100 $\mathrm{m}$ of rural site transects outside of Winnipeg's Perimeter Highway.

We used mowing frequency along ROWs $(0,1$, or 2 times/yr) and whether or not a ROW was hayed (yes $=1$, no $=0$ ) as predictors of abundance and occupancy of grassland birds, hypothesizing that mowing and haying may affect habitat suitability by altering vegetation structure along ROWs. Within Winnipeg's Perimeter Highway, Manitoba Hydro mows and sprays most of its transmission lines with a broadleaf herbicide $(2,4-\mathrm{D})$ at least twice a year, in the spring and fall, to control exotic weedy forbs such as Canada thistle (Cirsium arvense). Lines beyond Winnipeg's Perimeter Highway are mowed once a year or not at all except to remove trees under transmission line cables. Cut vegetation is left as mulch along transmission lines except along hayed transmission lines.

We also used measures of vegetation structure as variables predicting abundance and occupancy of grassland birds along ROWs. From mid-July to the end of August in either 2007 or 2008, we conducted vegetation surveys (two plots per site, spaced 300 $\mathrm{m}$ apart) at all sites to measure potential nesting habitat for grassland birds along ROWs. We did these surveys in 2007 if we first visited sites in 2007, and in 2008 at a small number of sites first visited in 2008 . We measured vegetation aspects that might be associated with the amount of nest cover for ground-nesting birds: percent woody plant cover, percent grass cover, percent litter cover, and percent bare ground. Each survey plot consisted of a 1000- $\mathrm{m}^{2}$ modified-Whittaker plot within which we recorded the presence of plant species, the percent cover of predominant plant species, and the cumulative cover of all native Manitoban plant species in $100.1-\mathrm{m}^{2}$ systematically spaced subplots (Kalkhan and Stohlgren 2000). We assigned percent cover of each ground cover type in each quadrat to cover classes $(0 \%$, trace $[>0-0.5 \%], 1[0.5-$ $1 \%$ ], 2 [1-3\%], 3 [3-10\%], 4 [10-25\%], 5 [25-50\%], 6 [50-75\%], 7 [75-90\%], 8 [90-100\%], 100\%) to produce consistent estimates of plant cover by different field technicians (Daubenmire 1959). For analyses, we converted these rankings to the mid-range values and summed the total live, upright grass stem cover of all graminoid species per quadrat, total woody plant stem cover of all woody plant species per quadrat, litter cover (dead, prostrate plant matter) per quadrat, and bare ground cover per quadrat. We then calculated average measures of grass cover (48 sites in 2007-2008: mean $=8.6 \% ; \mathrm{SD}=5.2 \%)$, woody plant cover $($ mean $=0.2 \% ; \mathrm{SD}$ $=0.7 \%)$, litter cover $($ mean $=74.9 \% ; \mathrm{SD}=13.3 \%)$, and bare ground cover $($ mean $=5.9 \% ; \mathrm{SD}=10.0 \%)$ among all 20 quadrats per site. We also measured vegetation height-density, i.e., the height (in $\mathrm{cm}$ ) at which $\geq 50 \%$ of a $10-\mathrm{cm}$ interval on a pole was concealed by vegetation from an observer $4 \mathrm{~m}$ away from the pole, with eye level at $1 \mathrm{~m}$ from the ground, at all 20 quadrats per site, and then averaged the vegetation height-density at each site (Robel et al. 1970; 48 sites in 2007-2008: mean $=23.6 \mathrm{~cm}$; $\mathrm{SD}=12.8 \mathrm{~cm}$ ).

Urban land within $100 \mathrm{~m}$ of transects (48 sites in 2007-2008: mean $=16.7 \%$; $\mathrm{SD}=16.4 \%$ ) was negatively correlated with wooded land within $100 \mathrm{~m}$ of transects (mean $=21.6 \%$; $\mathrm{SD}=23.6 \% ; r=$ $-0.46, P<0.0001)$. Grassland within $100 \mathrm{~m}$ was negatively correlated with wooded land within $100 \mathrm{~m}(r=-0.34, P<0.0001)$ but not with urban land within $100 \mathrm{~m}(r=0.07, P>0.1)$. Other correlation coefficients between land use and vegetation structural variables were weaker than the urban land-wooded land correlation, reducing multicollinearity issues in models. However, mowing frequency was strongly and positively correlated with the amount of urban land within $100 \mathrm{~m}$ of all sites $(r=0.60, P<0.0001)$. To remove this correlation, as part of a separate study of 20 of the 48 sites, we mowed three of the rural $500-\mathrm{m}$ transects twice and arranged for five of the urban 500-m 
transects to remain unmowed between August 2008 and August 2009 (Leston 2013). At both types of treatment sites, the treatment area was $500 \times 30 \mathrm{~m}$ wide ( 1.5 ha). Urban land within $100 \mathrm{~m}$ of transects was strongly correlated with mowing frequency at the 20 sites $(\rho=0.64, P<0.0001)$ before the mowing adjustment, but not afterward $(\rho=0.07, P=0.77$; Leston 2013).

\section{Statistical analyses}

\section{Hierarchical distance-sampling models}

To evaluate whether the detectability of birds varied with traffic noise and hence if urban declines of birds are due to masking of urban birds by environmental noise, we used distance-sampling methods (Buckland et al. 2005). Distance-sampling models allowed us to analyze effects of land use and local vegetation within ROWs on bird abundance and effects of distance of birds and traffic on detection probability, although the assumption of population closure meant that separate analyses had to be done for each year for each species. We ran hierarchical distancesampling models (Sillett et al. 2012) using the "gdistsamp" function in the unmarked package in R (Fiske and Chandler 2011), with one analysis per species per year (2007-2009), to model effects of site characteristics (land use within $100 \mathrm{~m}$, mowing regime) on densities of birds after accounting for effects of distance on detection probability, differences in effective detection radius (EDR) between "high traffic" and "low traffic" sites, and effects of Julian date, time of day, and observer on availability of birds for detection. We compared models in a multistep process, ranking the best model at each step by the Akaike Information Criterion (AIC) and using the best model as the null model in the next model step.

We only ran analyses for species with $\geq 60$ sightings across all visits and sites in a given year (Buckland et al. 2005). This limited our analyses to Clay-colored Sparrow and Savannah Sparrow in each year. We classified high traffic sites as those with $>11 \%$ of land within $100 \mathrm{~m}$ of site transects consisting of built-up urban lands such as office buildings, residential homes, parking lots, and roads. Low traffic sites had $<11 \%$ of land within $100 \mathrm{~m}$ of site transects consisting of built-up lands. We chose this cut-off to minimize the correlation between urbanization and traffic volume and because some rural sites outside Winnipeg's Perimeter Highway had higher traffic volumes and $>11 \%$ urban land within $100 \mathrm{~m}$, whereas a few urban sites within the Perimeter Highway were located in neighborhoods with few roads, more green space, and $<11 \%$ urban land within $100 \mathrm{~m}$ (iTrans Consulting 2009). We did not use traffic volume as a predictor because we only had measures of traffic volume from specific visits in 2007, and these measures were not always precise and would require a separate EDR to be estimated for each traffic level. We assigned individual birds from transects to four distance intervals $(0-5,6-10,11-15$, and $>15$ $\mathrm{m}$ ). In step 1, we tested for the distance function (half-normal, hazard, exponential, uniform) that best described how the number of detections per species per year declined with increasing distance interval. We tested seven models at this stage: models specifying a half-normal distance function with (1) no variables affecting EDR or (2) EDR varying between high and low traffic sites; models specifying a hazard distance function with (3) no variables affecting EDR or (4) EDR varying between high and low traffic sites; models specifying a exponential distance function with (5) no variables affecting EDR or (6) EDR varying between high and low traffic sites; and (7) a model specifying a uniform distance function, i.e., no decline in detection probability with increasing distance of birds within rights-of-way (Appendix 1).

In step 2, we modeled variables that potentially affect the availability of birds for detection. We tested eight models at this stage: (1) the best model from step 1; (2) availability for detection varying with Julian date; (3) availability varying with time of morning when a site was visited (hourly increments); (4) availability varying with observer; and (5-8) models with all possible additive combinations of Julian date, time of morning, and observer (Appendix 1).

In step 3, we modeled landscape variables that potentially affect the probability of presence and number of birds detected at each site in a particular analysis. We compared five models: (1) the best model from step 2; (2) a land use model incorporating the best step 2 model's effects on availability and EDR, where $P_{p} \sim$ urban land within $100 \mathrm{~m}+$ wooded lands (forests and shrublands) within $100 \mathrm{~m}$, and grasslands within $100 \mathrm{~m}$ (mowed, hayed, grazed, or unmowed); (3) an urban land model incorporating the best step 2 model's effects on availability and EDR, where $\mathrm{P}_{\mathrm{p}} \sim$ urban land within $100 \mathrm{~m}$; (4) a wooded land model, i.e., best step 2 model effects + wooded land within $100 \mathrm{~m}$; and (5) a grassland model, i.e., best step 2 model effects + grassland within 100 m (Appendix 1).

In step 4, we tested how grassland bird abundance along ROWs was potentially affected by either local vegetation management within ROWs or by within-ROW vegetation structure, which could vary with mowing and spraying regime. We compared the best model from step 3 to (1) a vegetation management model incorporating the best step 3 model's effects on availability and EDR, and in which $P_{p}$ was additionally related to mowing frequency (quadratic function) + hayed (yes $=1$, no $=0$ ); (2) a linear mowing model, i.e., best step 3 model effects + mowing frequency (linear function); (3) a hayed model, i.e., best step 3 model effects + hayed (yes $=1$, no $=0$ ); (4) a vegetation structure model incorporating the best step 3 model's effects on availability and EDR, and in which $\mathrm{P}_{\mathrm{p}}$ was additionally related to a site's mean percentage of grass cover, woody plant cover, litter cover, and bare ground cover, and mean vegetation height-density; (5) a grass cover model, i.e., best step 3 model effects + mean percentage of grass cover; (6) a woody cover model, i.e., best step 3 model effects + mean percentage of woody plant cover; (7) a litter cover model, i.e., best step 3 model effects + mean percentage of litter cover; (8) a bare ground cover model, i.e., best step 3 model effects + mean percentage of bare ground cover; and (9) a vegetation density model, i.e., best step 3 model effects + mean vegetation density (Appendix 1). Because we did not have vegetation survey data for all 48 sites in 2009, we did not run models that included vegetation structure variables in 2009 (models 4-9 in step 4).

We evaluated model parsimony in all four steps using the AIC (Burnham and Anderson 2002). We assessed goodness-of-fit of the best step 3 model using a Freeman-Tukey Chi-square test for count data (Sillett et al. 2012, Lituma and Buehler 2016). We judged goodness-of-fit to be adequate if the $P$ value associated with the Freeman-Tukey statistic was $>0.10$ (Sillett et al. 2012, Lituma and Buehler 2016; Appendix 1). 


\section{Multiseason occupancy models}

Multiseason occupancy models (MacKenzie et al. 2003, Kéry and Chandler 2016) allowed us to use $>1 \mathrm{yr}$ of data within an analysis to see if occupancy of ROWs by grassland birds was affected by surrounding land use or local vegetation management, and if a change in mowing management at the five urban and three rural treatment sites affected the probability across years of grassland birds newly settling or not returning to a particular ROW. Unlike hierarchical distance sampling, occupancy models cannot be used to analyze bird abundance or effects of distance on detection probability. We ran multiseason occupancy models using the "colext" function in the unmarked package in R (Fiske and Chandler 2011) to predict the probability of occupancy and probability of detection given occupancy at each site over 2 yr of visits with 3 visits/yr. We compared models in a multistep process, ranking the best model at each step by AIC and using the best model as the null model in the next model step.

Although we had 3 yr of occupancy data, we only ran multiseason occupancy models for 2008-2009. Because of a limitation of the "colext" function, all analyzed sites had to be visited in at least the first sampling period. Because we visited fewer sites in 2007 than in 2008, if we ran models starting in 2007, we would have been unable to use the sites first visited in 2008 in our models; thus, using just $2 \mathrm{yr}$ of data gave us more observations for multiseason occupancy models in $\mathrm{R}$ than using $3 \mathrm{yr}$ of data. Although other occupancy modeling software (PRESENCE) does not have this limitation, we used the "colext" function in unmarked because it allowed us to assess the goodness-of-fit of multiseason occupancy models. We ran models for Clay-colored Sparrow, Savannah Sparrow, Le Conte's Sparrow, and Western Meadowlark.

In step 1, we modeled variables that potentially affect the availability of birds for detection within a given visit to a site in a given year. We tested eight models at this stage: (1) a null model; (2) probability of detection varying with Julian date; (3) probability of detection varying with time of morning; (4) probability of detection varying with observer; and (5-8) models with all possible additive combinations of Julian date, time of morning, and observer.

We took the best model from step 1 and used it as the null model in steps 2 and 3, in which we modeled effects of changes in study sites that occurred from 2008 to 2009, specifically, the changes in mowing frequency at the five urban and three rural sites. In step 2 , we compared the null model from step 1 to: (1) a model in which mowing frequency at a site in a given year affected the probability that a species colonized a site in 2009 where it was absent in 2008; and (2) a model in which mowing frequency at a site in a given year affected the probability that a species failed to return to breed at a site in 2009 where it was present in 2008 . We did this to see if the experimental mowing treatment at the three rural sites increased or decreased the probability of species using those sites in 2009 or, conversely, if halting mowing at five urban experimental sites increased or decreased the probability of species using those sites in 2009.

In step 3, we compared five models: (1) the best model from step 2; (2) a land use model incorporating the best step 2 model's effects on availability, where $\mathrm{P}_{\mathrm{p}} \sim$ urban land within $100 \mathrm{~m}+$ wooded lands (forests + shrublands) within $100 \mathrm{~m}$, and grasslands within $100 \mathrm{~m}$ (mowed, hayed, grazed, or unmowed); (3) an urban land model incorporating the best step 2 model's effects on availability, where $\mathrm{P}_{\mathrm{p}} \sim$ urban land within $100 \mathrm{~m}$; (4) a wooded land model, i.e., best step 2 model effects + wooded land within $100 \mathrm{~m}$; and (5) a grassland model, i.e., best step 2 model effects + grassland within $100 \mathrm{~m}$.

As in the previous distance-sampling analyses in step 4, we tested how grassland bird abundance along ROWs is potentially affected by either local vegetation management within ROWs or by within-ROW vegetation structure. We compared the best model from step 3 to (1) a vegetation management model incorporating the best step 3 model's effects on availability and occupancy and in which $\mathrm{P}_{\mathrm{p}}$ was additionally related to mowing frequency (quadratic function) + hayed (yes $=1$, no $=0$ ); (2) a linear mowing model, i.e., best step 3 model effects + mowing frequency (linear function); (3) a hayed model, i.e., best step 3 model effects + hayed (yes $=1$, no $=0$ ); (4) a vegetation structure model incorporating the best step 3 model's effects on availability and occupancy and in which $\mathrm{P}_{\mathrm{p}}$ was additionally related to a site's mean percentage of grass cover, woody plant cover, litter cover, and bare ground cover, and mean vegetation heightdensity; (5) a grass cover model, i.e., best step 3 model effects + mean percentage of grass cover; (6) a woody cover model, i.e., best step 3 model effects + mean percentage of woody plant cover; (7) a litter cover model, i.e., best step 3 model effects + mean percentage of litter cover; (8) a bare ground cover model, i.e., best step 3 model effects + mean percentage of bare ground cover; and (9) a vegetation density model, i.e., best step 3 model effects + mean vegetation density.

We tested for adequate goodness-of-fit of the best final multiseason occupancy model for each species using the Mackenzie-Bailey Chi-square statistic. We judged goodness-offit to be adequate if the overall $P$ value (both years) and individual-year $P$ values associated with the Freeman-Tukey statistic were $>0.10$.

\section{RESULTS}

ROWs were inhabited primarily by a small number of generalist ground-nesting native grassland birds such as Savannah Sparrow and Clay-colored Sparrow, with smaller numbers of Le Conte's Sparrow and Western Meadowlark. Other native grassland birds such as Brown-headed Cowbird (Molothrus ater), Bobolink (Dolichonyx oryzivorus), Killdeer (Charadrius vociferus), Nelson's Sharp-tailed Sparrow (Ammodramus nelsoni), Sedge Wren, Vesper Sparrow (Poöcetes gramineus), and Wilson's Snipe (Gallinago delicata) were observed along several unmowed or hayed rural ROWs but were not abundant enough for modeling. Few exotics such as European Starling (Sturnus vulgaris) or House Sparrow (Passer domesticus) were observed to use the ROWs (Appendix 1). Mean traffic volumes (number of passing vehicles detected per minute of survey) recorded at site visits in 2007 varied from 0.04 along some rural ROWs to 9.91 along an urban ROW. Traffic speeds along many ROWs next to major roads or highways in Winnipeg varied from $50-80 \mathrm{~km} / \mathrm{h}$, and during some visits to urban ROWs in 2007, traffic volumes were too high to count accurately without losing focus during bird surveys (Appendix 1). 
Table 1. Effect sizes and 95\% confidence intervals (CIs) for variables from the highest ranking hierarchical distance-sampling models predicting Clay-colored Sparrow and Savannah Sparrow occurrences along 34 transmission line study sites in Winnipeg, Manitoba, Canada in 2007 (34 sites, $N=102$ surveys), 2008 (46 sites, $N=138$ surveys), and 2009 (44 sites, $N=132$ surveys). Models assume a uniform detection probability, and variables with $95 \%$ confidence intervals excluding zero are shown. Subscripts indicate year. More detailed results for each species in each year are provided in Appendix 2.

\begin{tabular}{|c|c|c|c|c|c|}
\hline Species & Density parameter & Estimate & SE (estimate) & 95\% CI (lower) & 95\% CI (upper) \\
\hline \multirow[t]{12}{*}{ Clay-colored Sparrow } & Wooded land within $100 \mathrm{~m}_{2007}$ & -0.0153 & 0.0055 & -0.0260 & -0.0046 \\
\hline & Mowing frequency (times/year) ${ }_{2007}$ & -0.1981 & 0.1390 & -0.4706 & 0.0744 \\
\hline & Mowing frequency ${ }_{2007}^{2}$ & 0.6854 & 0.3294 & 0.0397 & 1.3311 \\
\hline & Hayed $(\text { yes }=1)_{2007}$ & 0.8022 & 0.3694 & 0.0783 & 1.5261 \\
\hline & Urban land within $100 \mathrm{~m}_{2008}$ & -0.0297 & 0.0083 & -0.0461 & -0.0133 \\
\hline & Wooded land within $100 \mathrm{~m}_{2008}$ & -0.0182 & 0.0058 & -0.0296 & -0.0068 \\
\hline & Grassland within $100 \mathrm{~m}_{2008}$ & -0.0056 & 0.0055 & -0.0164 & 0.0052 \\
\hline & Woody plant cover $_{2008}$ & -1.6212 & 0.5149 & -2.6303 & -0.6120 \\
\hline & Litter cover $_{2008}$ & 0.0343 & 0.0125 & 0.0098 & 0.0588 \\
\hline & Urban land within $100 \mathrm{~m}_{2009}$ & -0.0284 & 0.0086 & -0.0452 & -0.0116 \\
\hline & Wooded land within $100 \mathrm{~m}_{2009}$ & -0.0150 & 0.0055 & -0.0258 & -0.0042 \\
\hline & Grassland within $100 \mathrm{~m}_{2009}$ & -0.0019 & 0.0043 & -0.0103 & 0.0064 \\
\hline \multirow[t]{8}{*}{ Savannah Sparrow } & Wooded land within $100 \mathrm{~m}_{2007}$ & -0.0452 & 0.0094 & -0.0636 & -0.0268 \\
\hline & Wooded land within $100 \mathrm{~m}_{2008}$ & -0.0349 & 0.0062 & -0.0470 & -0.0228 \\
\hline & Mowing frequency $_{2009}$ & 0.0088 & 0.1190 & -0.2243 & 0.2419 \\
\hline & Mowing frequency $_{2009}$ & 0.6713 & 0.2618 & 0.1581 & 1.1845 \\
\hline & Hayed $(\text { yes }=1)_{2009}$ & 1.0593 & 0.2714 & 0.5272 & 1.5914 \\
\hline & Urban land within $100 \mathrm{~m}_{2009}$ & -0.0309 & 0.0073 & -0.0452 & -0.0166 \\
\hline & Wooded land within $100 \mathrm{~m}_{2009}$ & -0.0346 & 0.0053 & -0.0449 & -0.0242 \\
\hline & Grassland within $100 \mathrm{~m}_{2009}$ & 0.0015 & 0.0034 & -0.0051 & 0.0081 \\
\hline
\end{tabular}

\section{Hierarchical distance-sampling models}

In each year that we analyzed Clay-colored Sparrow and Savannah Sparrow abundance (2007: 34 sites, 102 surveys; 2008: 46 sites, 138 surveys; 2009: 44 sites, 132 surveys), a model with a uniform key function always had a lower AIC than any model in which a key function (hazard, half-normal, or exponential) specified that detection probability of grassland birds varied with distance from observers on the transect line used in surveys, indicating no effect of distance to observer on detectability. Similarly, detection probability did not vary between high traffic and low traffic sites. This result indicates that for both Claycolored Sparrow and Savannah Sparrow, if measured abundance or occupancy of either species was lower along urban ROWs, it was not because of a lower probability of detecting birds at urban sites due to more traffic or noise at urban than rural sites.

Although the importance of individual factors varied among years, Clay-colored Sparrow was more likely to be detected with increasing Julian date and earlier in the morning (in 2008 and 2009; Appendix 2). Clay-colored Sparrow was less abundant along ROWs with more wooded lands within $100 \mathrm{~m}$ in all years, and along ROWs with more urban land within $100 \mathrm{~m}$ in 2008 and 2009 (Figs. 2-4, Table 1). After accounting for land use affecting abundance and factors affecting detection probability, vegetation management and vegetation structure within ROWs had more ambiguous effects on Clay-colored Sparrow abundance. In 2007, Clay-colored Sparrow responded inconsistently to mowing frequency (either increasing with haying or strongly declining with increasing mowing frequency), but increased with vegetation density and litter cover. In 2008, the species did not vary with mowing or vegetation density declined as woody plant cover increased (Table 1; Appendix 2, Tables A2.A-C). In contrast, in 2008, Clay-colored Sparrow densities did not decline with
Fig. 2. Predicted relationship for Clay-colored Sparrow (CCSP) and Savannah Sparrow (SAVS) densities based on the percentage of land within $100 \mathrm{~m}$ of study sites consisting of wooded lands (trees or shrubs) in 2007. The relationships are as determined by the best-ranked hierarchical distance-sampling model for each species in 2007.
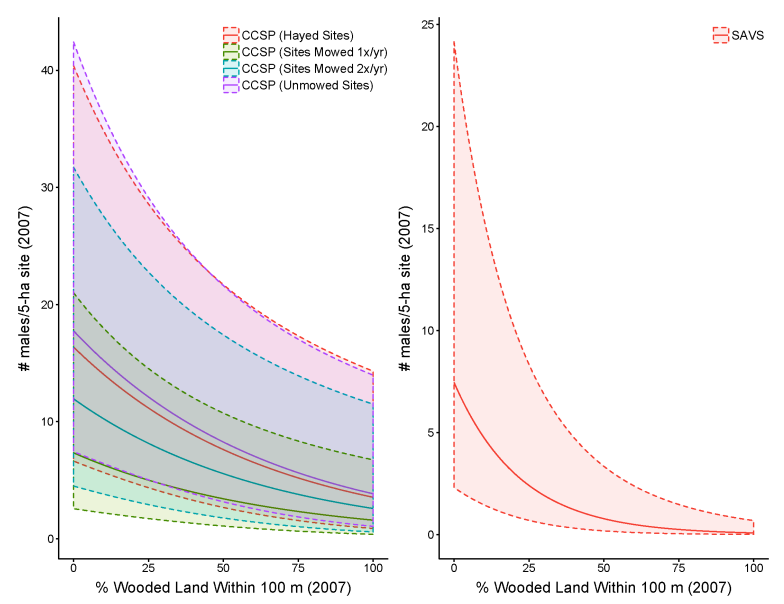

increased mowing frequency or increase with vegetation density along ROWs. Instead, Clay-colored Sparrow declined as woody plant cover increased and increased as litter cover increased (Table 1; Appendix 2, Table A2.D). In 2009, a model containing just land use effects (urban land + wooded land + grassland) was more parsimonious than other top models (Table 1; Appendix 2, Tables A2.E-G). 
Table 2. Highest ranking multiseason occupancy model for Clay-colored Sparrow along 47 transmission line study sites in Winnipeg, Manitoba, Canada in 2008-2009. AICc $=335.65, \Delta \mathrm{AICc}=0.00$, AIC weight $=0.37, N=276$ surveys. Total Mackenzie-Bailey chisquare $=13.62(P=0.19)$, Season $1=3.70(P=0.62)$, Season $2=9.92(P=0.06)$, c-hat $=1.31$. Coefficients from other high-ranking models $(\triangle \mathrm{AICc} \leq 2.00)$ are provided in Appendix 3.

\begin{tabular}{|c|c|c|c|c|c|}
\hline Parameter & Variable & Estimate & SE (estimate) & 95\% CI (lower) & $\begin{array}{l}95 \% \mathrm{CI} \\
\text { (upper) }\end{array}$ \\
\hline \multirow[t]{3}{*}{ Initial occupancy parameter } & Intercept & 2.8122 & 1.0458 & 0.7624 & 4.8619 \\
\hline & Wooded land within $100 \mathrm{~m}$ & -0.0555 & 0.0264 & -0.1072 & -0.0038 \\
\hline & Mowing Frequency & -1.5244 & 0.8598 & -3.2096 & 0.1608 \\
\hline Colonization probability parameter & Intercept & -0.3030 & 0.7050 & -1.6848 & 1.0788 \\
\hline Extinction probability parameter & Intercept & -3.0000 & 0.9920 & -4.9443 & -1.0557 \\
\hline \multirow[t]{6}{*}{ Detection probability parameter } & Intercept & -4.8022 & 2.3483 & -9.4049 & -0.1995 \\
\hline & Julian & 0.0372 & 0.0143 & 0.0091 & 0.0652 \\
\hline & Time2 & 0.0028 & 0.5401 & -1.0558 & 1.0614 \\
\hline & Time3 & -1.2269 & 0.5135 & -2.2333 & -0.2204 \\
\hline & Time4 & -0.45582 & 0.5379 & -1.5101 & 0.5985 \\
\hline & Time5 & -1.0480 & 0.6107 & -2.2450 & 0.1489 \\
\hline
\end{tabular}

Fig. 3. Predicted relationship for Clay-colored Sparrow (CCSP) and Savannah Sparrow (SAVS) densities based on the percentage of land within $100 \mathrm{~m}$ of study sites consisting of wooded lands (trees or shrubs; both species) and urban land (CCSP only) in 2008.

Relationships to both wooded and urban land were determined by the best-ranked hierarchical distancesampling model for each species in 2008.
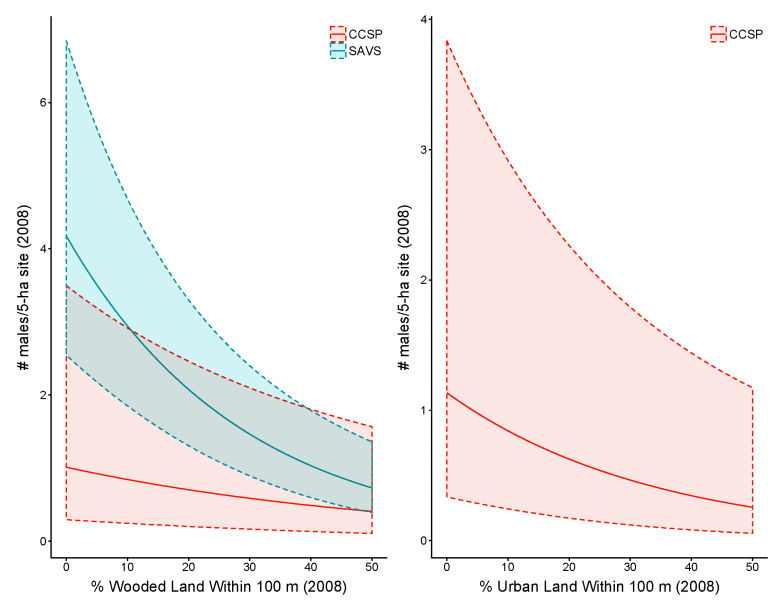

Depending on the year analyzed, Savannah Sparrow availability for detection increased with increasing Julian date, declined later in the morning, and increased for more experienced observers (Appendix 2, Tables A2.H-L). Savannah Sparrow was less abundant along ROWs surrounded by more wooded lands and along ROWs with more surrounding urban land in 2009 (Figs. 24, Table 1; Appendix 2, Tables A2.H-L). After accounting for detection probability and land use, there were few effects of vegetation management and structure in 2007 and 2008. However, in 2009, Savannah Sparrow densities were best predicted by the vegetation management model, in which Savannah Sparrow densities increased along ROWs that were mowed more frequently and within hayed ROWs relative to unhayed ROWs (Table 1; Appendix 2, Table A2.L).
Fig. 4. Predicted relationship for Clay-colored Sparrow (CCSP) and Savannah Sparrow (SAVS) densities based on the percentage of land within $100 \mathrm{~m}$ of study sites consisting of wooded lands (trees or shrubs) and urban land in 2009. Relationships to both wooded and urban land were determined by the best-ranked hierarchical distance-sampling model for each species in 2009.
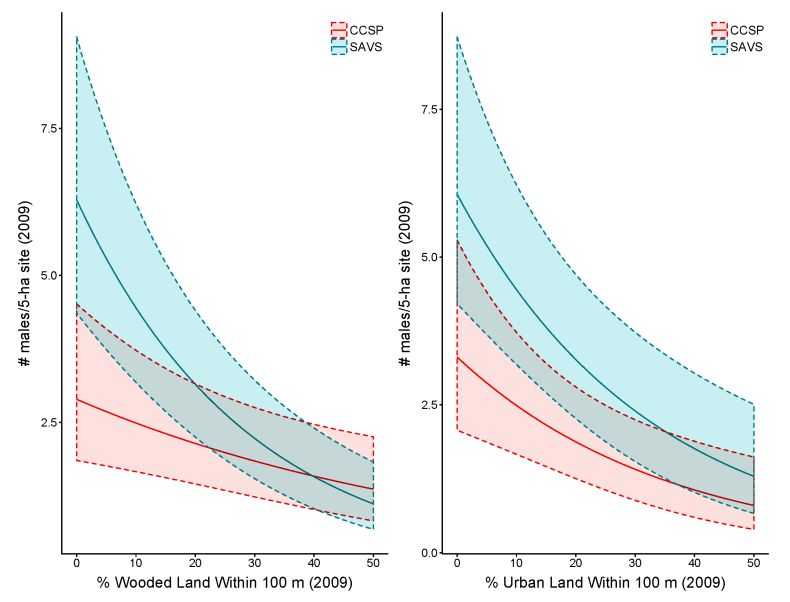

\section{Multiseason occupancy models}

Multiseason occupancy models ( $N=47$ sites, 276 surveys, with 6 surveys across 2 years at 45 of 47 sites and 1 year of 3 surveys at 2 of 47 sites), suggested similar effects of date, time, and experience as did the distance sampling models. The probability of detecting Clay-colored Sparrow increased with Julian date and declined later in the morning but did not vary with observer (Table 2; Appendix 3, Tables A3.A and A3.B), whereas the probability of detecting Savannah Sparrow increased with Julian date, did not vary with time in the morning, and was higher for experienced observers (Table 3). We did not find effects of Julian date, time in the morning, or observer on detection of Le Conte's Sparrow or Western Meadowlark (Tables 4 and 5). 
Table 3. Highest ranking multiseason occupancy model for Savannah Sparrow along 47 transmission line study sites in Winnipeg, Manitoba, Canada in 2008-2009. AICc $=250.89, \Delta \mathrm{AICc}=0.00$, AIC weight $=0.84, N=276$ surveys. Total Mackenzie-Bailey chisquare $=24.08(P=0.02)$, Season $1=5.18(P=0.35)$, Season $2=18.89(P=0.02)$, c-hat $=2.47$. Relative ranks of other models are provided in Appendix 4.

\begin{tabular}{|c|c|c|c|c|c|}
\hline Parameter & Variable & Estimate & SE (estimate) & $\begin{array}{l}95 \% \mathrm{CI} \\
\text { (lower) }\end{array}$ & $\begin{array}{l}95 \% \mathrm{CI} \\
\text { (upper) }\end{array}$ \\
\hline \multirow[t]{3}{*}{ Initial occupancy parameter } & Intercept & 179.1200 & 166.6100 & -147.4360 & 505.6756 \\
\hline & Wooded land within $100 \mathrm{~m}$ & -3.4400 & 3.1900 & -9.6924 & 2.8124 \\
\hline & Bare ground cover & -3.6900 & 4.3100 & -12.1376 & 4.7576 \\
\hline \multirow[t]{2}{*}{ Colonization probability parameter } & Intercept & -1.6100 & -1.1000 & 0.5460 & -3.7660 \\
\hline & Mowing frequency & -69.4000 & -474.4000 & 860.4240 & -999.2240 \\
\hline Extinction probability parameter & Intercept & -3.7300 & 1.1700 & -6.0232 & -1.4368 \\
\hline \multirow[t]{4}{*}{ Detection probability parameter } & Intercept & -5.3680 & 2.8506 & -10.9552 & 0.2192 \\
\hline & Julian & 0.0430 & 0.0179 & 0.0079 & 0.0781 \\
\hline & Observer (YK vs. LL) ${ }^{\dagger}$ & 0.4070 & 1.1189 & -1.7860 & 2.6000 \\
\hline & Observer (YW vs. LL) ${ }^{\dagger}$ & -1.5790 & 0.3871 & -2.33377 & -0.8203 \\
\hline
\end{tabular}

${ }^{\dagger}$ A positive effect (both $95 \%$ confidence limits for the point estimate $>0$ ) indicates that the observer in a given year (YK or YW) had a greater probability of detecting Savannah Sparrow per site visit than the observer used as a reference (LL); a negative observer effect (both $95 \%$ confidence limits for the point estimate $<0$ ) indicates that the observer was less likely to detect Savannah Sparrow per site visit.

Table 4. Highest ranking multiseason occupancy model for Le Conte's Sparrow along 47 transmission line study sites in Winnipeg, Manitoba, Canada in 2008-2009. AICc $=147.50, \Delta \mathrm{AICc}=0.00$, AIC weight $=0.29 \mathrm{~N}=276$ surveys. Total Mackenzie-Bailey chisquare $=6.62(P=0.67)$, Season $1=2.79(P=0.91)$, Season $2=3.83(P=0.67)$, c-hat $=0.58$. Coefficients for other high-ranking models $(\triangle \mathrm{AICc} \leq 2.00)$ are provided in Appendix 2. Relative ranks of other models are provided in Appendix 5.

\begin{tabular}{|c|c|c|c|c|c|}
\hline$\underline{\text { Parameter }}$ & Variable & Estimate & SE (estimate) & 95\% CI (lower) & 95\% CI (upper) \\
\hline \multirow[t]{3}{*}{ Initial occupancy parameter } & Intercept & -3.8650 & 2.3160 & -8.4044 & 0.6744 \\
\hline & Urban land within $100 \mathrm{~m}$ & -0.1220 & 0.1240 & -0.3650 & 0.1210 \\
\hline & Grass cover & 0.2650 & 0.1730 & -0.0741 & 0.6041 \\
\hline Colonization probability parameter & Intercept & -1.0600 & 0.4250 & -1.8930 & -0.2270 \\
\hline Extinction probability parameter & Intercept & -2.5200 & 3.4700 & -9.3212 & 4.2812 \\
\hline Detection probability parameter & Intercept & -0.1480 & 0.3500 & -0.8340 & 0.5380 \\
\hline
\end{tabular}

Table 5. Highest ranking multiseason occupancy model for Western Meadowlark along 47 transmission line study sites in Winnipeg, Manitoba, Canada in 2008-2009. AICc $=255.90, \Delta \mathrm{AICc}=0.00$, AIC weight $=0.34, N=276$ surveys. Total Mackenzie-Bailey chisquare $=5.42(P=0.92)$, Season $1=2.19(P=0.76)$, Season $2=3.24(P=0.76)$, c-hat $=0.47$. Coefficients from other high-ranking models $(\triangle \mathrm{AICc} \leq 2.00)$ are provided in Appendix 2. Relative ranks of other models are provided in Appendix 6.

\begin{tabular}{|c|c|c|c|c|c|}
\hline Parameter & Variable & Estimate & SE (estimate) & $95 \%$ CI (lower) & $95 \% \mathrm{CI}$ (upper) \\
\hline \multirow[t]{5}{*}{ Initial occupancy parameter } & Intercept & -2.3658 & 1.5973 & -5.4954 & 0.7649 \\
\hline & Urban land within $100 \mathrm{~m}$ & -0.0413 & 0.0340 & -0.1079 & 0.0253 \\
\hline & Grassland within $100 \mathrm{~m}$ & 0.0865 & 0.0321 & 0.0236 & 0.1494 \\
\hline & Woodland within $100 \mathrm{~m}$ & -0.0694 & 0.0364 & -0.1407 & 0.0019 \\
\hline & Hayed & 2.5723 & 1.4427 & -0.2554 & 5.4000 \\
\hline Colonization probability parameter & Intercept & -1.7600 & 0.7660 & -3.2614 & -0.2586 \\
\hline Extinction probability parameter & Intercept & -3.2300 & 3.1300 & -9.3648 & 2.9048 \\
\hline Detection probability parameter & Intercept & -0.1810 & 0.2070 & -0.5867 & 0.2247 \\
\hline
\end{tabular}


The probabilities of extinction at sites occupied in 2008 or colonization of previously unoccupied sites did not vary with mowing among sites, except for Savannah Sparrow (Table 3). For Savannah Sparrow, the probability of colonization increased from 2008 to 2009 at sites that were newly mowed in 2009 . However, uncertainty in the estimated effect of mowing on Savannah Sparrow colonization was high, and an effect of mowing was only recognized because of the much lower AIC of that model than for an otherwise identical model in which colonization probability was identical at all sites. Although this result was ambiguous, it was consistent with a positive effect of mowing frequency on Savannah Sparrow abundance in distance-sampling models from 2009.

After accounting for detection probability, effects of surrounding land use on the probability of grassland bird species occupying ROWs were consistent with those land use effects found in our distance-sampling models. Savannah Sparrow and Clay-colored Sparrow occupancy declined as the amount of wooded land increased within $100 \mathrm{~m}$ of ROWs (Figs. 4 and 5, Tables 2 and 3; Appendix 3, Tables A3.A and A3.B). Le Conte's Sparrow occupancy declined as the amount of urban land increased within $100 \mathrm{~m}$ of ROWs (Table 4; Appendix 3, Tables A3.C and A3.D). Western Meadowlark occupancy increased with grassland amount and declined with wooded land amount within $100 \mathrm{~m}$ of study sites (Fig. 6, Table 5; Appendix 3, Tables A3.E and A3.F).

Fig. 5. Predicted relationship for Clay-colored Sparrow (CCSP) and Savannah Sparrow (SAVS) initial probability of site occupancy based on the percentage of land within $100 \mathrm{~m}$ of study sites consisting of wooded lands (trees or shrubs). Relationships are as determined by the best-ranked multiseason occupancy model for each species in 2008-2009. Prediction curves for CCSP show declining probability of occupancy ( $\Psi)$ with increasing mowing frequency at sites.
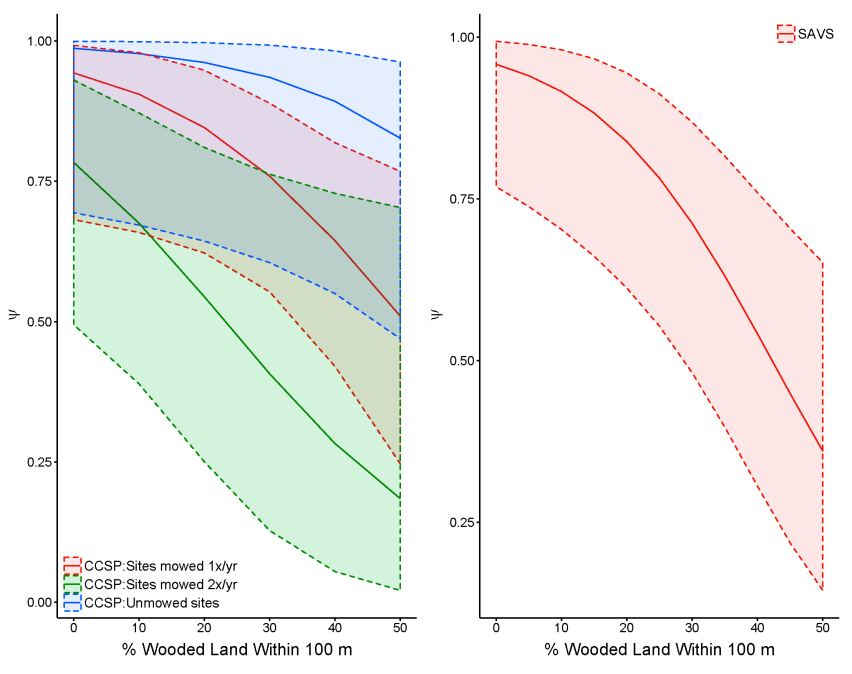

After accounting for surrounding land use, grassland bird occupancy of ROWs showed species-specific responses to vegetation management or structure along ROWs. Clay-colored Sparrow occupancy decreased as mowing frequency increased along ROWs (Table 2; Appendix 3, Tables A3.A and A3.B). Savannah Sparrow occupancy declined as percent bare ground increased within sites and with increasing amount of wooded lands within $100 \mathrm{~m}$ of study sites (Table 3). Le Conte's Sparrow occupancy increased with increasing percent grass cover within sites (Table 4; Appendix 3, Tables A3.C and A3.D), and Western Meadowlark occupancy did not vary with any vegetation management or structural variables (Table 5).

Fig. 6. Predicted relationship for Western Meadowlark initial probability of site occupancy based on the percentage of land within $100 \mathrm{~m}$ of study sites consisting of wooded lands (trees or shrubs) and urban land. Relationships are as determined by the best-ranked multiseason occupancy model for Western Meadowlark in 2008-2009. Prediction curves show increasing probability of occupancy $(\Psi)$ with increasing amount of grassland within $100 \mathrm{~m}$ of sites.
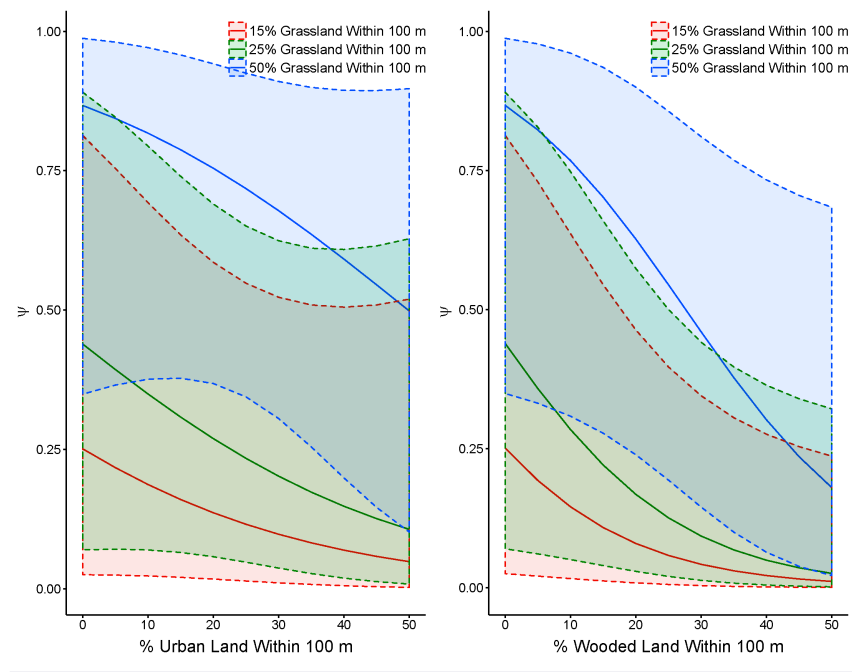

\section{DISCUSSION}

To our knowledge, our study is the first urban bird study to evaluate different effects of urban landscapes on bird abundance after accounting for potential differences in detection probability among sites due to traffic volumes and noise (Ingelfinger and Anderson 2004, Blickley and Patricelli 2012, Lituma and Buehler 2016), time of season, time of morning, and observer experience (Farnsworth et al. 2002). Using two different methods for measuring effects of land use and mowing regime on grassland birds allowed us to account for more potential variables affecting the detectability of birds among sites and visits. Although the assumptions of each modeling approach differ, some results were similar, illustrating how the methods corroborated and complemented each other's results in our study.

Surrounding land use potentially affects the habitat suitability of ROWs that might be prioritized for management as grassland bird habitats. We generally found negative effects of amount of wooded land and, to a lesser extent, amount of urban land on grassland bird abundance or occupancy. Land-use effects in our study are consistent with previous studies showing declines of grassland birds with increasing urbanization (Bock et al. 1999, Engle et al. 1999, Haire et al. 2000), in the presence of roads (Lituma and Buehler 2016), and in increasingly wooded landscapes (Bakker et al. 2002). Our results suggest that when 
selecting urban ROWs to manage as grassland bird habitats, ROWs with fewer built-up urban lands or wooded lands within $100 \mathrm{~m}$ may be most effective. Surprisingly, the amount of grassland within $100 \mathrm{~m}$ of study sites did not have a strong effect on abundance or occupancy for most of our focal species. Because the amount of grassland was negatively correlated with the amount of wooded land but not with urban land within $100 \mathrm{~m}$ of the study sites, grassland birds in general may have had less habitat within ROWs in wooded landscapes. However, larger grassland areas such as wider ROWs sometimes occurred where there were larger amounts of urban land within $100 \mathrm{~m}$ of study sites; hence, surrounding urbanization may have weakened the effect of grassland area on abundance or occupancy by these species. In contrast, we observed a positive effect of amount of grassland on occupancy by Western Meadowlark. This species is considerably larger than other species in our study and may have had larger area requirements for territories (Davis and Lanyon 2008), making the amount of grassland within $100 \mathrm{~m}$ of ROWs a more important factor for this species.

We found varying evidence of effects of mowing regime and vegetation structure on grassland bird abundance or occupancy along urban ROWs. Presumably, varying effects of mowing on grassland bird abundance or occupancy relate to its effects on vegetation structure, which could affect nesting habitat available to shrub-nesting or ground-nesting birds along ROWs. In a previous study, we found significantly lower vegetation height, vegetation density, and grass cover along mowed ROWs than unmowed ROWs (Leston and Koper 2016). Clay-colored Sparrow tended to respond negatively to increases in mowing frequency or urban land amount near ROWs, possibly because frequently mowed ROWs (including urban ROWs) had a lower volume of herbaceous vegetation available for this species as required for nesting (Knapton 1994). The lack of similar mowing effects on Le Conte's Sparrow was surprising given that this species also nests in tall, dense vegetation (Lowther 2005); however, Le Conte's Sparrow occupancy was less likely as urbanization increased around ROWs, perhaps masking the effects of vegetation management. We were surprised by the positive effect of haying on Clay-colored Sparrow and Savannah Sparrow abundance and the negative effect of woody plant cover in 2008 on Clay-colored Sparrow abundance given that Claycolored Sparrow nests in shrubs (Knapton 1994); this result is also inconsistent with some previous studies that concluded that Savannah Sparrow declines with increasing haying or mowing (Dale et al. 1997). However, other studies suggest that Savannah Sparrow increases after mowing (Roth et al. 2005). Other species that might increase in unmowed grasslands (Sedge Wren; Murray and Best 2003, Roth et al. 2005), mowed grasslands (Grasshopper Sparrow; Eastern Meadowlark, Sturnella magna; Murray and Best 2003, Roth et al. 2005), or idle native grasslands (Baird's Sparrow, Ammodramus bairdii; Sprague's Pipit, Anthus spragueii; Dale et al. 1997) were either absent or rare in our study area.

Whereas reducing mowing frequency along urban ROWs could create more habitat for grassland birds associated with tall herbaceous vegetation (Knapton 1994, Lowther 2005), it is plausible that a mixture of unmowed and hayed grasslands along ROWs would allow urban ROWs to support more grassland bird species (Dale et al. 1997, Murray and Best 2003, Roth et al. 2005). Although it was not investigated here, mowing might affect habitat for grassland birds through changes in food availability. In another study, we also observed greater numbers or biomass of many types of potential arthropod prey for grassland birds along hayed and infrequently mowed ROWs than along frequently mowed ROWs (Leston 2013), which might have made the vegetation along hayed ROWs more attractive as foraging habitat for grassland birds. Mowing associated with haying creates fresh, nutritious regrowth for herbivorous arthropods (Seastedt 1985), although mowing and haying may also remove habitat for arthropods (Seastedt 1985, Morris and Rispin 1988) that serve as prey for grassland birds; because many grassland birds have strong preferences for sites with different vegetation structures (Murray and Best 2003, Roth et al. 2005), a mixture of mowed and unmowed sections of urban ROWs managed as grassland bird habitats might provide appropriate arthropod prey and nest sites for more species of grassland birds. Dale et al. (1997) suggest leaving unmowed patches idle for at least three years while mowing other patches in alternate years to favor a mixture of bird species associated with both low-growing and dense herbaceous vegetation. Similarly, urban ROW managers might leave $50 \%$ of individual ROW sections unmowed for three or so years, except where necessary for safety concerns, and mow 50\% of ROW sections every second year. Emphasizing unmowed ROWs might benefit rarer grassland birds in the study area such as Bobolink, Le Conte's Sparrow, and Sedge Wren, or Baird's Sparrow and Sprague's Pipit along ROWs with native prairie in the mixed-grass prairie region west of Manitoba (Dale et al. 1997, McMaster et al. 2005).

Although some species such as Savannah Sparrow may increase with mowing or haying, greater abundance or occupancy of such species in mowed or hayed habitats does not necessarily indicate that mowing will improve the productivity of these species. Mowed ROWs may function as ecological traps for birds (Donovan and Thompson 2001). Mowing or haying along ROWs is typically timed to control weeds or harvest a crop; if nests are still active by the date of mowing along urban ROWs, such nests will usually be destroyed (Kershner and Bollinger 1996, McMaster et al. 2005). If mowing or haying is used as a wildlife management tool along urban ROWs, reducing haying or mowing frequency or delaying haying (or mowing without haying) until after the breeding season (for example, after July 15, as in Saskatchewan) may prevent the destruction of most bird nests (Kershner and Bollinger 1996, Dale et al. 1997, McMaster et al. 2005, Nocera et al. 2005).

Although the detectability of bird songs may vary with environmental factors such as ambient noise (Brumm 2004, Nemeth et al. 2013), and our urban study sites had larger amounts of nearby traffic (iTrans Consulting 2009), we did not find significant differences in detection of Clay-colored Sparrow or Savannah Sparrow between high traffic and low traffic sites. We also did not find declines in the detection of individual birds with increasing distance from transects along ROWs. This is consistent with several previous studies that found little effect of industrial or road noise on detectability of grassland birds (Koper et al. 2015, Lituma and Buehler 2016). The lack of a distance effect may be because our transects were relatively narrow, so that all birds in potential grassland habitat were close enough not to be masked by traffic noise (e.g., see also Koper et al. 2015). It is possible that the Clay-colored Sparrow and Savannah Sparrow 
we analyzed sang at frequencies high enough and amplitudes loud enough not to be masked by traffic (Brumm 2004, Nemeth et al. 2013); perhaps this explanation could be tested in future studies using portable acoustic recorders to measure traffic volume and bird song amplitudes and frequencies from recordings (Shonfield and Bayne 2017). Nevertheless, these results suggest that fewer detections of grassland birds at urban sites in our study were due to lower actual abundance of birds at urban sites and were not an artifact of detectability. Our results also suggest that abundance-modeling techniques that do not use detection distance-sampling methods are acceptable for narrow transect surveys in urban landscapes. Apart from traffic noise, we found broadly similar effects of time of season, time of morning, and observer experience on detection of different grassland bird species, consistent with previous studies (Farnsworth et al. 2002), whether we used hierarchical distance-sampling models or multiseason occupancy models to account for these factors affecting detectability.

Grassland birds as a group are declining across North America, probably due to a combination of habitat conversion and agricultural intensification (Herkert 1994, Peterjohn and Sauer 1999) and urbanization (Bock et al. 1999, Engle et al. 1999, Haire et al. 2000). Managing underused urban grassy spaces such as ROWs for grassland birds may help these species to persist in urban environments and may help to replace grassland habitats lost through anthropogenic habitat conversion. Understanding which ROWs should be the focus of conservation efforts and how vegetation should be managed within focal ROWs are the first steps in this direction. Our models suggest that grassland bird management efforts should focus on ROWs with minimal surrounding urban or wooded lands within which the mowing regime can be adjusted to benefit focal species (i.e., reduced mowing in parts of urban ROWs for species such as Le Conte's Sparrow, haying or infrequent mowing in other parts of urban ROWs for other species such as Savannah Sparrow). Urban ROWs could potentially provide thousands of kilometers of habitat in the Great Plains (Morgan et al. 1995, Ries et al. 2001), and could provide alternative habitats not only for grassland birds but for many other species associated with grasslands.

Responses to this article can be read online at: http://www.ace-eco.org/issues/responses.php/1049

\section{Acknowledgments:}

This study was funded by the Manitoba Hydro Research and Development Grant (\#G237), National Science and Engineering Research Canada Industrial Postgraduate Scholarship (IPS1-350445-2007), Manitoba Conservation Sustainable Development Innovations Fund (\#27095/26082), Environment Canada's Science Horizons Fund (SH215), Manitoba Career Focus Program, and the University of Manitoba's Faculty of Graduate Studies. Academic advice for this study came from Dr. Micheline Manseau, Dr. Terry Galloway, and Dr. Douglas Johnson. Field work was conducted by Praepun Khattiyakornjaroon, Jennifer Tran, and Yan Wang. Inkind support was provided by Dr. Robert Roughley and Technician Dave Holder (University of Manitoba, Department of
Entomology); Tamara Keedwell and Dalia Naguib (University of Manitoba, Natural Resources Institute); and Wade Munro, Trent Hreno, Wayne Ortiz, and Spencer Heaman (Manitoba Hydro liaisons and vegetation managers). Vegetation at the experimental sites was mowed by Manitoba Hydro personnel (Wayne Ortiz, Spencer Heaman) and Neil van Ryssel (agricultural producer, Oakbank, Manitoba).

\section{LITERATURE CITED}

Anderson, D. R. 2001. The need to get the basics right in wildlife field studies. Wildlife Society Bulletin 29:1294-1297.

Bakker, K. K., D. E. Naugle, and K. F. Higgins. 2002. Incorporating landscape attributes into models for migratory grassland bird conservation. Conservation Biology 16:1638-1646. http://dx.doi.org/10.1046/j.1523-1739.2002.01328.x

Bibby, C. J., N. P. Burgess, and D. A. Hill. 1992. Territory mapping methods. Pages 42-65 in C. J. Bibby, N. D. Burgess, and D. A. Hill, editors. Bird census techniques. First edition. Academic Press, London, UK.

Blickley, J. L., and G. L. Patricelli. 2010. Impacts of anthropogenic noise on wildlife: research priorities for the development of standards and mitigation. Journal of International Wildlife Law and Policy 13:274-292. http://dx.doi. org/10.1080/13880292.2010.524564

Bock, C. E., J. H. Bock, and B. C. Bennett. 1999. Songbird abundance in grasslands at a suburban interface on the Colorado High Plains. Studies in Avian Biology 19:131-136.

Brumm, H. 2004. The impact of environmental noise on song amplitude in a territorial bird. Journal of Animal Ecology 73:434-440. http://dx.doi.org/10.1111/j.0021-8790.2004.00814.x

Buckland, S. T., D. R. Anderson, K. P. Burnham, and J. L. Laake, editors. 2005. Distance sampling. Wiley, Hoboken, New Jersey, USA.

Burnham, K. P., and D. R. Anderson. 2002. Model selection and multi-model inference: a practical information-theoretic approach. Second edition. Springer, New York, New York, USA.

Byrne, L. B. 2005. Of looks, laws and lawns: how human aesthetic preferences influence landscape management, public policies and urban ecosystems. Pages 42-46 in D. Laband, editor. Emerging issues along urban-rural interfaces. Linking Science and Society conference proceedings. Auburn University, Auburn, Alabama, USA.

Dale, B. C., P. A. Martin, and P. S. Taylor. 1997. Effects of hay management on grassland songbirds in Saskatchewan. Wildlife Society Bulletin 25:616-626.

Daubenmire, R. 1959. A canopy-coverage method of vegetational analysis. Northwest Science 33:43-64.

Davis, S. K., and W. E. Lanyon. 2008. Western Meadowlark (Sturnella neglecta). In P. Rodewald, editor. The birds of North America online. Cornell Lab of Ornithology, Ithaca, New York, USA. [online] URL: http://bna.birds.cornell.edu/bna/species/120

Donovan, T. M., and F. R. Thompson III. 2001. Modeling the ecological trap hypothesis: a habitat and demographic analysis 
for migrant songbirds. Ecological Applications 11:871-882. http:// dx.doi.org/10.1890/1051-0761(2001)011[0871:MTETHA]2.0.CO;2

Engle, D. M., T. L. Criner, J. C. Boren, R. E. Masters, and M. S. Gregory. 1999. Response of breeding birds in the Great Plains to low density urban sprawl. Great Plains Research 9:55-73.

Environmental Systems Research Institute (ESRI). 2002. ArcGIS. Release 8.3. ESRI, Redlands, California, USA.

Farnsworth, G. L., K. H. Pollock, J. D. Nichols, T. R. Simons, J. E. Hines, and J. R. Sauer. 2002. A removal model for estimating detection probabilities from point-count surveys. Auk 119:414-425. http://dx.doi.org/10.1642/0004-8038(2002)119[0414: ARMFED]2.0.CO;2

Fenner, M., and L. Palmer. 1988. Grassland management to promote diversity: creation of a patchy sward by mowing and fertilizer regimes. Field Studies 9:313-324.

Fiske, I., and R. Chandler. 2011. Unmarked: an R package for fitting hierarchical models of wildlife occurrence and abundance. Journal of Statistical Software 43:1-23. http://dx.doi. org/10.18637/jss.v043.i10

Haire, S. L., C. E. Bock, B. S. Cade, and B. C. Bennett. 2000. The role of landscape and habitat characteristics in limiting abundance of grassland nesting songbirds in an urban open space. Landscape and Urban Planning 48:65-82. http://dx.doi. org/10.1016/S0169-2046(00)00044-X

Hansen, A. J., R. L. Knight, J. M. Marzluff, S. Powell, K. Brown, P. H. Gude, and K. Jones. 2005. Effects of exurban development on biodiversity: patterns, mechanisms, and research needs. Ecological Applications 15:1893-1905. http://dx.doi.org/10.1890/05-5221

Herkert, J. R. 1994. The effects of habitat fragmentation on Midwestern grassland bird communities. Ecological Applications 4:461-471. http://dx.doi.org/10.2307/1941950

Hovd, H., and A. Skogen. 2005. Plant species in arable field margins and road verges of central Norway. Agriculture, Ecosystems, and Environment 110:257-265. http://dx.doi. org/10.1016/j.agee.2005.04.013

Ingelfinger, F., and S. Anderson. 2004. Passerine response to roads associated with natural gas extraction in a sagebrush steppe habitat. Western North American Naturalalist 64:385-395.

iTrans Consulting. 2009. 2007 Winnipeg area travel survey results - final report. iTrans Consulting, Toronto, Canada.

Kalkhan, M. A., and T. J. Stohlgren. 2000. Using multi-scale sampling and spatial cross-correlation to investigate patterns of plant species richness. Environmental Monitoring and Assessment 64:591-605. http://dx.doi.org/10.1023/A:1006329707198

Kershner, E. L., and E. K. Bollinger. 1996. Reproductive success of grassland birds at east-central Illinois airports. American Midland Naturalist 136:358-366. http://dx.doi.org/10.2307/2426740

Kéry, M., and R. Chandler. 2016. Dynamic occupancy models in unmarked. Self-published. [online] URL: https://cran.r-project. org/web/packages/unmarked/vignettes/colext.pdf

Knapton, R. W. 1994. Clay-colored Sparrow (Spizella pallida). In P. Rodewald, editor. The birds of North America online. Cornell
Lab of Ornithology, Ithaca, New York, USA. [online] URL: http://bna.birds.cornell.edu/bna/species/120

Koper, N., L. Leston, T. Baker, C. Curry, and P. Rosa. 2015. Effects of ambient noise on detectability and localization of avian songs and tones by observers in grasslands. Ecology and Evolution 6:245-255. http://dx.doi.org/10.1002/ece3.1847

Kruess, A., and T. Tscharntke. 2002. Contrasting responses of plant and insect diversity to variation in grazing intensity. Biological Conservation 106:293-302. http://dx.doi.org/10.1016/ S0006-3207(01)00255-5

Leston, L. 2013. Transmission lines as tall-grass prairie habitats: local mowing, spraying, and surrounding urbanization as determinants of wildlife richness and abundance. Dissertation. University of Manitoba, Winnipeg, Canada.

Leston, L., and N. Koper. 2016. Urban rights-of-way as reservoirs for tall-grass prairie plants and butterflies. Environmental Management 57:543-557. http://dx.doi.org/10.1007/s00267-015-0631-9

Lituma, C. M., and D. A. Buehler. 2016. Minimal bias in surveys of grassland birds from roadsides. Condor 118:715-727. http://dx. doi.org/10.1650/CONDOR-16-73.1

Lowther, P. E. 2005. Le Conte's Sparrow (Ammodramus leconteii). In P. Rodewald, editor. The birds of North America online. Cornell Lab of Ornithology, Ithaca, New York, USA. [online] URL: http://bna.birds.cornell.edu/bna/species/224

MacKenzie, D. I., J. D. Nichols, J. E. Hines, M. G. Knutson, and A. B. Franklin. 2003. Estimating site occupancy, colonization, and local extinction when a species is detected imperfectly. Ecology 84:2200-2207. http://dx.doi.org/10.1890/02-3090

McDonald, R. I., P. Kareiva, and R. T. T. Forman. 2008. The implications of current and future urbanization for global protected areas and biodiversity conservation. Biological Conservation 141:1695-1703. http://dx.doi.org/10.1016/j.

biocon.2008.04.025

McKinney, M. L. 2002. Urbanization, biodiversity, and conservation. Bioscience 52:883-890. http://dx.doi.org/10.1641/0006-3568 (2002)052[0883:UBAC]2.0.CO;2

McMaster, D. G., J. H. Devries, and S. K. Davis. 2005. Grassland birds nesting in haylands of southern Saskatchewan: landscape influences and conservation priorities. Journal of Wildlife Management 69:211-221. http://dx.doi.org/10.2193/0022-541X (2005)069<0211:GBNIHO>2.0.CO;2

Morgan, J. P., D. R. Collicut, and J. D. Thompson. 1995. Restoring Canada's native prairies: a practical manual. Prairie Habitats, Argyle, Canada.

Morris, M. G., and W. E. Rispin. 1988. A beetle fauna of oolitic limestone grassland, and the responses of species in conservation management by different cutting régimes. Biological Conservation 43:87-105. http://dx.doi.org/10.1016/0006-3207(88)90084-5

Munguira, M. L., and J. A. Thomas. 1992. Use of road verges by butterfly and burnet populations, and the effect of roads on adult dispersal and mortality. Journal of Applied Ecology 29:316-329. http://dx.doi.org/10.2307/2404501 
Murray, L. D., and L. B. Best. 2003. Short-term bird response to harvesting switchgrass for biomass in Iowa. Journal of Wildlife Management 67:611-621. http://dx.doi.org/10.2307/3802718

Nemeth, E., N. Pieretti, S. A. Zollinger, N. Geberzahn, J. Partecke, A. C. Miranda, and H. Brumm. 2013. Bird song and anthropogenic noise: vocal constraints may explain why birds sing higher-frequency songs in cities. Proceedings of the Royal Society B 280:20122798. http://dx.doi.org/10.1098/rspb.2012.2798

Nocera, J. J., G. J. Parsons, G. R. Milton, and A. H. Freedom. 2005. Compatibility of delayed cutting regime with bird breeding and hay nutritional quality. Agriculture, Ecosystems, and Environment 107:245-253. http://dx.doi.org/10.1016/j.agee.2004.11.001

Parr, T. W., and J. M. Way. 1988. Management of roadside vegetation: the long-term effects of cutting. Journal of Applied Ecology 25:1073-1087. http://dx.doi.org/10.2307/2403767

Peterjohn, B. G., and J. R. Sauer. 1999. Population status of North American grassland birds from the North American Breeding Bird Survey, 1966-1996. Studies in Avian Biology 19:27-44.

Ries, L., D. M. Debinski, and M. L. Wieland. 2001. Conservation value of roadside prairie restoration to butterfly communities. Conservation Biology 15:401-411. http://dx.doi.org/10.1046/ j.1523-1739.2001.015002401.x

Robel, R. J., J. N. Briggs, A. D. Dayton, and L. C. Hulbert. 1970. Relationships between visual obstruction measurements and weight of grassland vegetation. Journal of Range Management 23:295-297. http://dx.doi.org/10.2307/3896225

Roth, A. M., D. W. Sample, C. A. Ribic, L. Paine, D. K. Undersander, and G. A. Bartelt. 2005. Grassland bird response to harvesting switchgrass as a biomass energy crop. Biomass and Bioenergy 28:490-498. http://dx.doi.org/10.1016/j.biombioe.2004.11.001

Schippers, P., and W. Joenje. 2002. Modelling the effect of fertiliser, mowing, disturbance and width on the biodiversity of plant communities of field boundaries. Agriculture, Ecosystems and Environment 93:351-365. http://dx.doi.org/10.1016/S0167-8809 (01)00339-5

Seastedt, T. R. 1985. Maximization of primary and secondary productivity by grazers. American Naturalist 126:559-564. http:// dx.doi.org/10.1086/284437

Shonfield, J., and E. M. Bayne. 2017. Autonomous recording units in avian ecological research: current use and future applications. Avian Conservation and Ecology 12(1):14. http://dx.doi. org/10.5751/ACE-00974-120114

Sillett, T. S., R. B. Chandler, J. A. Royle, M. Kery, and S. A. Morrison. 2012. Hierarchical distance-sampling models to estimate population size and habitat-specific abundance of an island endemic. Ecological Applications 22:1997-2006. http://dx. doi.org/10.1890/11-1400.1
Swengel, A. B. 2001. A literature review of insect responses to fire, compared to other conservation managements of open habitat. Biodiversity Conservation 10:1141-1169. http://dx.doi. org/10.1023/A:1016683807033

Young, T. P. 2000. Restoration ecology and conservation biology. Biological Conservation 92:73-83. http://dx.doi.org/10.1016/ S0006-3207(99)00057-9

Zimdahl, R. L. 2007. Fundamentals of weed science. Third edition. Academic Press, Burlington, Maryland, USA.
Editor-in-Chief: Ryan Norris Subject Editor: Erica Nol
Sponsored by the Society of Canadian Ornithologists and Bird Studies Canada Parrainée par la Société des ornithologistes du Canada et Études d'oiseaux Canada

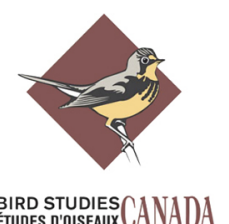


APPENDIX 1. Mean number of shorebirds or male songbirds of each species per visit along transmission line study sites in Winnipeg, Manitoba, Canada in 2007-2009 (44 sites, $n=132$ surveys), along with number of visits to each site over 3 years, mean traffic volume (number of passing vehicles/minute of survey time) per site visit in 2007, and proportion of land within $100 \mathrm{~m}$ of transmission lines consisting of built-up urban lands.

\begin{tabular}{|c|c|c|c|c|c|c|c|c|c|c|c|c|c|}
\hline Site & $\begin{array}{l}\text { Mean } \\
\text { Traffic } \\
\text { Volume } \\
\text { per } \\
\text { Minute* }\end{array}$ & $\begin{array}{l}\% \\
\text { Urban } \\
\text { Land } \\
\text { Within } \\
100 \mathrm{~m}\end{array}$ & $\begin{array}{l}\# \\
\text { Visits } \\
\text { Across } \\
3 \\
\text { Years }\end{array}$ & $\begin{array}{l}\text { Brown- } \\
\text { headed } \\
\text { Cowb- } \\
\text { ird }\end{array}$ & $\begin{array}{l}\text { Bobol- } \\
\text { ink }\end{array}$ & $\begin{array}{l}\text { Clay- } \\
\text { colour- } \\
\text { ed } \\
\text { Sparrow }\end{array}$ & Killdeer & $\begin{array}{l}\text { Le } \\
\text { Conte's } \\
\text { Sparrow }\end{array}$ & $\begin{array}{l}\text { Savan- } \\
\text { nah } \\
\text { Sparrow }\end{array}$ & $\begin{array}{l}\text { Sedge } \\
\text { Wren }\end{array}$ & $\begin{array}{l}\text { Vesper } \\
\text { Sparrow }\end{array}$ & $\begin{array}{l}\text { Western } \\
\text { Mead- } \\
\text { owlark }\end{array}$ & $\begin{array}{l}\text { Wilson's } \\
\text { Snipe }\end{array}$ \\
\hline 206east & 0.10 & 2.95 & 9 & 0.22 & 0.00 & 3.33 & 0.00 & 0.00 & 4.33 & 0.00 & 0.00 & 0.00 & 0.00 \\
\hline 206south & 0.32 & 11.57 & 9 & 0.11 & 0.00 & 0.78 & 0.00 & 0.00 & 3.44 & 0.00 & 0.00 & 0.67 & 0.00 \\
\hline 206west & 0.34 & 1.84 & 9 & 0.11 & 0.33 & 2.56 & 0.00 & 0.11 & 3.44 & 1.22 & 0.33 & 0.00 & 0.00 \\
\hline 207south & 0.49 & 12.73 & 9 & 0.11 & 0.00 & 3.22 & 0.00 & 0.00 & 5.22 & 0.11 & 0.00 & 1.00 & 0.00 \\
\hline Anola & 0.39 & 8.59 & 9 & 0.11 & 0.00 & 1.00 & 0.00 & 0.78 & 0.11 & 0.00 & 0.00 & 0.00 & 0.00 \\
\hline $\begin{array}{l}\text { Bishop Grandin } \\
\text { D }\end{array}$ & 2.94 & 38.34 & 9 & 0.22 & 0.00 & 0.22 & 0.00 & 0.00 & 1.00 & 0.00 & 0.00 & 0.00 & 0.00 \\
\hline $\begin{array}{l}\text { Bishop Grandin } \\
\text { E }\end{array}$ & 9.91 & 39.71 & 3 & 0.00 & 0.00 & 0.11 & 0.00 & 0.00 & 0.33 & 0.00 & 0.00 & 0.00 & 0.00 \\
\hline $\begin{array}{l}\text { Bishop Grandin } \\
\text { I }\end{array}$ & 1.65 & 24.76 & 9 & 0.00 & 0.00 & 0.67 & 0.00 & 0.00 & 2.89 & 0.00 & 0.00 & 0.33 & 0.00 \\
\hline $\begin{array}{l}\text { Bishop Grandin } \\
\mathbf{J}\end{array}$ & - & 25.61 & 6 & 0.00 & 0.00 & 0.17 & 0.00 & 0.00 & 1.83 & 0.00 & 0.00 & 0.33 & 0.00 \\
\hline Bradley & - & 64.54 & 6 & 0.17 & 0.00 & 2.50 & 0.00 & 0.00 & 0.17 & 0.17 & 0.00 & 0.33 & 0.00 \\
\hline Brady & - & 0.00 & 6 & 0.17 & 0.00 & 0.33 & 0.00 & 0.17 & 2.83 & 0.00 & 0.17 & 0.00 & 0.00 \\
\hline Bud & - & 55.21 & 3 & 0.00 & 0.00 & 0.00 & 0.00 & 0.00 & 0.17 & 0.00 & 0.00 & 0.00 & 0.00 \\
\hline Cooks Creek & 0.10 & 2.79 & 9 & 0.67 & 0.00 & 3.33 & 0.00 & 0.00 & 2.44 & 0.00 & 0.00 & 0.00 & 0.00 \\
\hline Dakota & - & 42.05 & 6 & 0.00 & 0.00 & 0.83 & 0.00 & 0.00 & 0.50 & 0.00 & 0.00 & 0.00 & 0.00 \\
\hline Dogpark & - & 0.00 & 6 & 0.17 & 0.00 & 1.50 & 0.00 & 0.83 & 4.17 & 0.00 & 0.33 & 0.00 & 0.00 \\
\hline Eastdale & 0.04 & 5.03 & 9 & 0.00 & 0.00 & 0.22 & 0.00 & 0.78 & 0.00 & 0.00 & 0.00 & 0.00 & 0.00 \\
\hline Fairview & - & 8.77 & 3 & 0.00 & 0.00 & 0.00 & 0.00 & 0.00 & 0.00 & 0.00 & 0.00 & 0.00 & 0.00 \\
\hline Garven B & 2.20 & 4.60 & 9 & 0.00 & 0.00 & 0.00 & 0.00 & 0.00 & 0.00 & 0.00 & 0.00 & 0.00 & 0.00 \\
\hline Garven F & 0.12 & 9.04 & 9 & 0.00 & 0.11 & 2.11 & 0.00 & 1.67 & 3.44 & 0.00 & 0.11 & 0.00 & 0.00 \\
\hline Gros Iles & 2.40 & 35.10 & 6 & 0.00 & 0.00 & 0.50 & 0.00 & 0.00 & 0.67 & 0.00 & 0.17 & 0.00 & 0.00 \\
\hline Heatherdale & 0.07 & 14.79 & 9 & 0.11 & 0.00 & 1.33 & 0.00 & 0.00 & 4.00 & 0.00 & 0.56 & 0.50 & 0.00 \\
\hline Lagimodiere & 0.10 & 1.15 & 9 & 0.22 & 0.00 & 1.78 & 0.00 & 0.00 & 2.89 & 0.00 & 0.00 & 0.50 & 0.00 \\
\hline Leila & 0.56 & 55.70 & 9 & 0.00 & 0.00 & 0.44 & 0.00 & 0.00 & 1.78 & 0.00 & 0.00 & 0.17 & 0.00 \\
\hline Mailhiot & 7.46 & 5.37 & 9 & 0.00 & 0.11 & 0.22 & 0.00 & 0.00 & 0.33 & 0.00 & 0.00 & 0.00 & 0.00 \\
\hline Maple Grove & - & 29.98 & 6 & 0.00 & 0.00 & 0.00 & 0.00 & 0.17 & 2.17 & 0.17 & 0.00 & 0.00 & 0.00 \\
\hline MC18 & 0.17 & 0.00 & 9 & 0.00 & 0.00 & 0.11 & 0.00 & 0.00 & 0.00 & 0.00 & 0.00 & 0.00 & 0.00 \\
\hline McGillivray & 2.11 & 19.05 & 9 & 0.00 & 0.00 & 0.78 & 0.00 & 0.00 & 3.00 & 0.00 & 0.00 & 0.50 & 0.00 \\
\hline Oakbank & - & 3.47 & 6 & 0.00 & 0.00 & 3.00 & 0.00 & 0.00 & 3.67 & 0.17 & 0.00 & 0.67 & 0.00 \\
\hline Pleasant & 0.04 & 4.27 & 9 & 0.00 & 0.00 & 0.44 & 0.00 & 0.00 & 0.00 & 0.00 & 0.00 & 0.00 & 0.00 \\
\hline Plessis & 3.89 & 25.59 & 9 & 0.11 & 0.00 & 1.33 & 0.00 & 0.22 & 2.11 & 0.00 & 0.00 & 0.67 & 0.00 \\
\hline Portage A & 0.22 & 7.32 & 9 & 0.00 & 0.00 & 1.89 & 0.00 & 0.00 & 0.89 & 0.00 & 0.00 & 0.33 & 0.00 \\
\hline Portage B & 0.16 & 10.22 & 9 & 0.00 & 0.00 & 1.78 & 0.33 & 0.11 & 1.44 & 0.11 & 0.11 & 0.17 & 0.00 \\
\hline Portage D & 0.11 & 7.89 & 9 & 0.11 & 0.00 & 1.89 & 0.00 & 0.11 & 2.00 & 0.00 & 0.11 & 0.17 & 0.33 \\
\hline Sapton & 0.10 & 8.88 & 9 & 0.00 & 0.00 & 0.67 & 0.00 & 0.00 & 0.00 & 0.00 & 0.00 & 0.00 & 0.00 \\
\hline Scurfield & - & 42.78 & 6 & 0.17 & 0.00 & 1.00 & 0.00 & 0.00 & 1.33 & 0.00 & 0.00 & 0.00 & 0.00 \\
\hline Shorehill & - & 19.87 & 6 & 0.00 & 0.00 & 2.67 & 0.00 & 0.00 & 1.33 & 0.00 & 0.00 & 0.00 & 0.00 \\
\hline Southside & 3.82 & 10.02 & 9 & 0.00 & 0.00 & 2.11 & 0.00 & 0.00 & 5.33 & 0.00 & 0.00 & 0.67 & 0.00 \\
\hline Spruce & 0.09 & 1.63 & 9 & 0.00 & 0.22 & 1.00 & 0.00 & 0.56 & 2.00 & 0.11 & 0.00 & 0.00 & 0.00 \\
\hline St. Mary & - & 34.63 & 6 & 0.00 & 0.00 & 0.67 & 0.00 & 0.00 & 2.17 & 0.00 & 0.00 & 0.33 & 0.00 \\
\hline Stoneridge & 0.04 & 2.24 & 9 & 0.00 & 0.00 & 0.89 & 0.00 & 0.44 & 0.00 & 0.00 & 0.00 & 0.00 & 0.00 \\
\hline Sugar Factory & 0.28 & 18.14 & 9 & 0.22 & 0.00 & 0.78 & 0.33 & 0.00 & 1.33 & 0.00 & 0.00 & 0.50 & 0.00 \\
\hline
\end{tabular}




\begin{tabular}{|c|c|c|c|c|c|c|c|c|c|c|c|c|c|}
\hline WarrenX $2 \mathrm{w}$ & 1.20 & 11.80 & 9 & 0.00 & 0.00 & 0.78 & 0.00 & 0.00 & 1.56 & 0.00 & 0.11 & 0.00 & 0.00 \\
\hline WarrenX3e & 1.97 & 15.24 & 9 & 0.00 & 0.00 & 0.89 & 0.00 & 0.00 & 1.44 & 0.00 & 0.00 & 0.00 & 0.00 \\
\hline WarrenX $5 \mathrm{e}$ & 2.47 & 11.25 & 9 & 0.11 & 0.00 & 1.89 & 0.00 & 0.00 & 1.44 & 0.00 & 0.22 & 0.33 & 0.00 \\
\hline Whyteridge & 1.51 & 42.74 & 9 & 0.33 & 0.00 & 1.11 & 0.00 & 0.00 & 0.67 & 0.00 & 0.00 & 0.00 & 0.00 \\
\hline Wilkes & 1.55 & 8.77 & 9 & 0.00 & 0.00 & 0.89 & 0.00 & 0.22 & 0.78 & 0.11 & 0.11 & 0.33 & 0.00 \\
\hline Willowdale & 0.04 & 8.77 & 9 & 0.00 & 0.22 & 0.56 & 0.00 & 0.44 & 0.67 & 0.22 & 0.00 & 0.50 & 0.00 \\
\hline Zora & 0.10 & 4.64 & 9 & 0.00 & 0.00 & 1.44 & 0.00 & 0.11 & 0.00 & 0.00 & 0.78 & 0.00 & 0.00 \\
\hline
\end{tabular}


Table A2.A. Highest-ranking hierarchical distance-sampling model $\left(\mathrm{AIC}_{\mathrm{c}}=482.52, \Delta \mathrm{AIC}_{\mathrm{c}}=0.00\right.$, AIC weight=0.34) for Clay-coloured Sparrows along 34 transmission line study sites in Winnipeg, Manitoba, Canada in 2007 ( $\mathrm{n}=102$ surveys), assuming a uniform detection probability with increasing distance of birds from the transect line and no effects of Julian date, time of morning, or observer experience on availability for detection.

\begin{tabular}{|c|c|c|c|c|}
\hline Density Parameter & Estimate & SE (Estimate) & 95\% C.I. (Lower) & 95\% C.I. (Upper) \\
\hline Intercept & 1.99 & 0.54 & 0.94 & 3.04 \\
\hline Wooded Land Within $100 \mathrm{~m}$ & -0.02 & 0.01 & -0.03 & -0.00 \\
\hline Mowing frequency (x/year) & -0.20 & 0.14 & -0.47 & 0.07 \\
\hline Mowing frequency $^{2}$ & 0.69 & 0.33 & 0.04 & 1.33 \\
\hline Hayed $($ yes $=1)$ & 0.80 & 0.37 & 0.08 & 1.53 \\
\hline Availability Parameter & Estimate & SE (Estimate) & 95\% C.I. (Lower) & 95\% C.I. (Upper) \\
\hline Intercept & -2.95 & 0.47 & -3.88 & -2.02 \\
\hline
\end{tabular}


Table A2.B. Second-highest-ranking hierarchical distance-sampling model $\left(\mathrm{AIC}_{\mathrm{c}}=484.67\right.$, $\Delta \mathrm{AIC}_{\mathrm{c}}=2.15$, AIC weight $=0.12$ ) for Clay-coloured Sparrows along 34 transmission line study sites in Winnipeg, Manitoba, Canada in 2007 ( $\mathrm{n}=102$ surveys), assuming a uniform detection probability with increasing distance of birds from the transect line and no effects of Julian date, time of morning, or observer experience on availability for detection.

\begin{tabular}{lllll}
\hline Density Parameter & Estimate & SE (Estimate) & $95 \%$ C.I. (Lower) & $95 \%$ C.I. (Upper) \\
Intercept & 2.61 & 0.64 & 1.35 & 3.87 \\
$\begin{array}{l}\text { Wooded Land Within 100 } \\
\text { m }\end{array}$ & -0.02 & 0.01 & -0.03 & -0.01 \\
Mowing frequency & -0.23 & 0.14 & -0.51 & 0.05 \\
& & & & \\
Availability Parameter & Estimate & SE (Estimate) & $95 \%$ C.I. (Lower) & $95 \%$ C.I. (Upper) \\
Intercept & -2.94 & 0.68 & -4.28 & -1.60 \\
\hline
\end{tabular}


Table A2.C. Third-highest-ranking hierarchical distance-sampling model $\left(\mathrm{AIC}_{\mathrm{c}}=484.83\right.$, $\Delta \mathrm{AIC}_{\mathrm{c}}=2.31$, AIC weight=0.11) for Clay-coloured Sparrows along 34 transmission line study sites in Winnipeg, Manitoba, Canada in 2007 ( $\mathrm{n}=102$ surveys), assuming a uniform detection probability with increasing distance of birds from the transect line and no effects of Julian date, time of morning, or observer experience on availability for detection.

\begin{tabular}{lllll}
\hline Density Parameter & Estimate & SE (Estimate) & $95 \%$ C.I. (Lower) & $95 \%$ C.I. (Upper) \\
Intercept & 2.39 & 0.52 & 1.37 & 3.40 \\
$\begin{array}{l}\text { Wooded Land Within 100 } \\
\text { m }\end{array}$ & -0.02 & 0.01 & -0.03 & -0.01 \\
Vegetation Density & 0.01 & 0.01 & -0.00 & 0.03 \\
& & & & \\
Availability Parameter & Estimate & SE (Estimate) & $95 \%$ C.I. (Lower) & $95 \%$ C.I. (Upper) \\
Intercept & -3.04 & 0.49 & -3.99 & -2.09 \\
\hline
\end{tabular}


Table A2.D. Highest ranking hierarchical distance-sampling model for Clay-coloured Sparrows $\left(\mathrm{AIC}_{\mathrm{c}}=683.13, \Delta \mathrm{AIC}_{\mathrm{c}}=0.00, \mathrm{AIC}\right.$ weight $\left.=0.73\right)$ along 46 transmission line study sites in Winnipeg, Manitoba, Canada in 2008 ( $\mathrm{n}=138$ surveys), assuming a uniform detection probability with increasing distance of birds from the transect line and effects of Julian date and time of morning but not observer experience on availability for detection.

\begin{tabular}{lllll}
\hline Density Parameter & Estimate & SE (Estimate) & $95 \%$ C.I. (Lower) & $95 \%$ C.I. (Upper) \\
Intercept & -0.82 & 1.40 & -3.55633 & 1.92 \\
Urban Land Within $100 \mathrm{~m}$ & -0.03 & 0.01 & -0.05 & -0.01 \\
Grassland Within $100 \mathrm{~m}$ & -0.01 & 0.01 & -0.02 & 0.01 \\
Wooded Land Within $100 \mathrm{~m}$ & -0.02 & 0.01 & -0.03 & -0.01 \\
Woody Plant Cover & -1.62 & 0.51 & -2.63 & -0.61 \\
Grass Cover & 0.03 & 0.02 & -0.01 & 0.07 \\
Vegetation Density & -0.003 & 0.01 & -0.02 & 0.02 \\
Bare ground Cover & 0.02 & 0.02 & -0.01 & 0.05 \\
Litter Cover & 0.03 & 0.01 & 0.01 & 0.06 \\
& & & & \\
Availability Parameter & Estimate & SE (Estimate) & $95 \%$ C.I. (Lower) & $95 \%$ C.I. (Upper) \\
Intercept & -4.53 & 1.91 & -8.28 & -0.78 \\
Julian & 0.02 & 0.01 & 0.00 & 0.05 \\
Time2 & -0.36 & 0.35 & -1.05 & 0.34 \\
Time3 & -0.98 & 0.36 & -1.69 & -0.27 \\
Time4 & -0.42 & 0.31 & -1.03 & 0.19 \\
Time5 & -1.12 & 0.40 & -1.90 & -0.34 \\
\hline Freeman-They X
\end{tabular}

Freeman-Tukey $\mathrm{X}^{2}=136$, mean (original-bootstrapped statistic)=-93.3, S.E.=9.16, P>0.998. 
Table A2.E. Highest-ranking hierarchical distance-sampling model $\left(\mathrm{AIC}_{\mathrm{c}}=676.15, \Delta \mathrm{AIC}_{\mathrm{c}}=0.00\right.$, AIC weight=0.33) for Clay-coloured Sparrows along 44 transmission line study sites in Winnipeg, Manitoba, Canada in 2009 ( $\mathrm{n}=132$ surveys), assuming a uniform detection probability with increasing distance of birds from the transect line and effects of Julian date and time of morning but not observer experience on availability for detection.

\begin{tabular}{lllll}
\hline Density Parameter & Estimate & $\begin{array}{l}\text { SE } \\
\text { (Estimate) }\end{array}$ & $95 \%$ C.I. (Lower) & $95 \%$ C.I. (Upper) \\
Intercept & 1.26 & 0.35 & 0.57078 & 1.95 \\
Mowing frequency & -0.24 & 0.15 & -0.53 & 0.06 \\
Urban Land Within $100 \mathrm{~m}$ & -0.02 & 0.01 & -0.04 & -0.00 \\
Grassland Within 100 m & -0.001 & 0.004 & -0.01 & 0.01 \\
Wooded Land Within 100 & -0.01 & 0.005 & -0.03 & -0.00 \\
m & & & & \\
& & & & \\
Availability Parameter & Estimate & SE & $95 \%$ C.I. (Lower) & $95 \%$ C.I. (Upper) \\
& & (Estimate) & & -6.21 \\
Intercept & -5.28 & -0.48 & -4.35 & 0.05 \\
Julian & 0.03 & 0.01 & 0.014 & -1.11 \\
Time2 & -0.44 & -0.34 & 0.24 & -1.84 \\
Time3 & -1.12 & -0.37 & -0.39 & -1.33 \\
Time4 & -0.59 & -0.388 & 0.15 & -2.48 \\
Time5 & -1.32 & -0.59 & -0.17 & \\
\hline
\end{tabular}

Freeman-Tukey $\mathrm{X}^{2}=151$, mean (original-bootstrapped statistic) $=-11.9$, S.E.=7.26, $\mathrm{P}=0.96$. 
Table A2.F. Second-highest-ranking hierarchical distance-sampling model $\left(\mathrm{AIC}_{\mathrm{c}}=676.55\right.$, $\Delta \mathrm{AIC}_{\mathrm{c}}=0.39$, AIC weight $=0.27$ ) for Clay-coloured Sparrows along 44 transmission line study sites in Winnipeg, Manitoba, Canada in 2009 ( $\mathrm{n}=132$ surveys), assuming a uniform detection probability with increasing distance of birds from the transect line and effects of Julian date and time of morning but not observer experience on availability for detection.

\begin{tabular}{lllll}
\hline Density Parameter & Estimate & SE (Estimate) & $95 \%$ C.I. (Lower) & $95 \%$ C.I. (Upper) \\
Intercept & 1.42 & 0.33 & 0.78 & 2.07 \\
Urban Land Within $100 \mathrm{~m}$ & -0.03 & 0.01 & -0.05 & -0.01 \\
Grassland Within $100 \mathrm{~m}$ & -0.00 & 0.00 & -0.01 & 0.01 \\
Wooded Land Within 100 & -0.015 & 0.006 & -0.03 & -0.00 \\
$\mathrm{~m}$ & & & & \\
& & & & \\
Availability Parameter & Estimate & SE (Estimate) & $95 \%$ C.I. (Lower) & $95 \%$ C.I. (Upper) \\
Intercept & -5.37 & 1.49 & -8.29 & -2.44 \\
Julian & 0.03 & 0.01 & 0.01 & 0.05 \\
Time2 & -0.49 & 0.35 & -1.18 & 0.19 \\
Time3 & -1.16 & 0.37 & -1.89 & -0.43 \\
Time4 & -0.62 & 0.39 & -1.38 & 0.14 \\
Time5 & -1.39 & 0.60 & -2.56 & -0.22 \\
\hline
\end{tabular}


Table A2.G. Third-highest-ranking hierarchical distance-sampling model $\left(\mathrm{AIC}_{\mathrm{c}}=676.73\right.$, $\Delta \mathrm{AIC}_{\mathrm{c}}=0.58$, AIC weight $=0.25$ ) for Clay-coloured Sparrows along 44 transmission line study sites in Winnipeg, Manitoba, Canada in 2009 ( $\mathrm{n}=132$ surveys), assuming a uniform detection probability with increasing distance of birds from the transect line and effects of Julian date and time of morning but not observer experience on availability for detection.

\begin{tabular}{lllll}
\hline Density Parameter & Estimate & SE (Estimate) & $95 \%$ C.I. (Lower) & $95 \%$ C.I. (Upper) \\
Intercept & 0.95 & 0.42 & 0.12 & 1.78 \\
Mowing frequency & -0.15 & 0.17 & -0.48 & 0.17 \\
Mowing frequency2 & 0.56 & 0.33 & -0.09 & 1.20 \\
Hayed (yes=1) & 0.56 & 0.36 & -0.14 & 1.26 \\
Urban Land Within 100 m & -0.02 & 0.01 & -0.04 & -0.00 \\
Grassland Within 100 m & -0.002 & 0.005 & -0.01 & 0.01 \\
Wooded Land Within 100 & -0.015 & 0.006 & -0.03 & -0.00 \\
m & & & & \\
& & & & \\
Availability Parameter & Estimate & SE (Estimate) & $95 \%$ C.I. (Lower) & $95 \%$ C.I. (Upper) \\
Intercept & -5.53 & -1.47 & -2.64 & -8.42 \\
Julian & 0.03 & 0.01 & 0.01 & 0.05 \\
Time2 & -0.37 & -0.34 & 0.30 & -1.04 \\
Time3 & -1.03 & -0.37 & -0.30 & -1.75 \\
Time4 & -0.56 & -0.38 & 0.18 & -1.30 \\
Time5 & -1.23 & -0.60 & -0.06 & -2.41 \\
\hline
\end{tabular}


Table A2.H. Highest-ranking hierarchical distance-sampling model $\left(\mathrm{AIC}_{\mathrm{c}}=430.26, \Delta \mathrm{AIC}_{\mathrm{c}}=0.00\right.$, AIC weight=0.20) for Savannah Sparrows along 34 transmission line study sites in Winnipeg, Manitoba, Canada in 2007 ( $\mathrm{n}=102$ surveys), assuming a uniform detection probability with increasing distance of birds from the transect line and effects of time of morning and observer experience but not Julian date on availability for detection.

\begin{tabular}{lrrrr}
\hline Density Parameter & Estimate & SE (Estimate) & $95 \%$ C.I. (Lower) & $95 \%$ C.I. (Upper) \\
Intercept & 1.14 & 0.97 & -0.75 & 3.04 \\
Wooded Land Within 100 & & & & \\
$\mathrm{m}$ & -0.04 & 0.01 & -0.06 & -0.03 \\
Litter cover & 0.01 & 0.01 & -0.00 & 0.03 \\
& & & & \\
Availability Parameter & Estimate & SE (Estimate) & $95 \%$ C.I. (Lower) & $95 \%$ C.I. (Upper) \\
Intercept & -2.44 & 0.82 & -4.05 & -0.84 \\
Time2 & -0.56 & 0.39 & -1.33 & 0.20 \\
Time3 & 0.11 & 0.35 & -0.58 & 0.79 \\
Time4 & -0.01 & 0.34 & -0.69 & 0.66 \\
Time5 & 0.66 & 0.39 & -0.11 & 1.44 \\
Obs (LL vs. JT) & 0.62 & 0.23 & 0.16 & 1.07 \\
\hline
\end{tabular}

Freeman-Tukey $\mathrm{X}^{2}=90.6$, mean (original-bootstrapped statistic) $=-2.84$, S.E. $=6.14, \mathrm{P}>0.67$. 
Table A2.I. Second-highest-ranking hierarchical distance-sampling model $\left(\mathrm{AIC}_{\mathrm{c}}=430.59\right.$, $\Delta \mathrm{AIC}_{\mathrm{c}}=0.31$, AIC weight $=0.17$ ) for Savannah Sparrows along 34 transmission line study sites in Winnipeg, Manitoba, Canada in 2007 ( $\mathrm{n}=102$ surveys), assuming a uniform detection probability with increasing distance of birds from the transect line and effects of time of morning and observer experience but not Julian date on availability for detection.

\begin{tabular}{lrrrr}
\hline Density Parameter & Estimate & SE (Estimate) & $95 \%$ C.I. (Lower) & $95 \%$ C.I. (Upper) \\
Intercept & 2.01 & 0.60 & 0.83 & 3.18 \\
Wooded Land Within 100 & & & & \\
$\mathrm{m}$ & -0.05 & 0.01 & -0.06 & -0.03 \\
& & & & \\
Availability Parameter & Estimate & SE (Estimate) & $95 \%$ C.I. (Lower) & $95 \%$ C.I. (Upper) \\
Intercept & -2.31 & 0.71 & -3.71 & -0.91 \\
Time2 & -0.55 & 0.40 & -1.32 & 0.23 \\
Time3 & 0.16 & 0.35 & -0.53 & 0.86 \\
Time4 & -0.01 & 0.35 & -0.70 & 0.67 \\
Time5 & 0.69 & 0.40 & -0.10 & 1.48 \\
Obs (LL vs. JT) & 0.62 & 0.24 & 0.16 & 1.09 \\
\hline
\end{tabular}


Table A2.J. Third-highest-ranking hierarchical distance-sampling model $\left(\mathrm{AIC}_{\mathrm{c}}=430.85\right.$, $\Delta \mathrm{AIC}_{\mathrm{c}}=0.58$, AIC weight $=0.15$ ) for Savannah Sparrows along 34 transmission line study sites in Winnipeg, Manitoba, Canada in 2007 ( $\mathrm{n}=102$ surveys), assuming a uniform detection probability with increasing distance of birds from the transect line and effects of time of morning and observer experience but not Julian date on availability for detection.

\begin{tabular}{lrrrrr}
\hline $\begin{array}{l}\text { Density Parameter } \\
\text { Intercept }\end{array}$ & Estimate & SE (Estimate) & $\begin{array}{l}\text { 95\% C.I. } \\
\text { (Lower) }\end{array}$ & \multicolumn{2}{c}{$\begin{array}{c}\text { 95\% C.I. } \\
\text { (Upper) }\end{array}$} \\
Wooded Land Within 100 & 2.19 & 0.67 & 0.88 & 3.49 \\
$\mathrm{~m}$ & & & & -0.06 & -0.03 \\
Bare ground Cover & -0.05 & 0.01 & -0.05 & 0.01 \\
& -0.021 & 0.017 & & \multicolumn{2}{c}{$95 \%$ C.I. } \\
Availability Parameter & Estimate & SE (Estimate) & 95\% C.I. & & (Lower) \\
Intercept & -2.36 & 0.76 & -3.85 & -0.86 \\
Time2 & -0.57 & 0.39 & -1.34 & 0.21 \\
Time3 & 0.07 & 0.36 & -0.63 & 0.77 \\
Time4 & -0.04 & 0.35 & -0.73 & 0.64 \\
Time5 & 0.69 & 0.40 & -0.10 & 1.47 \\
Obs (LL vs. JT) & 0.62 & 0.23 & 0.16 & 1.08 \\
\hline
\end{tabular}


Table A2.K. Final hierarchical distance-sampling model for Savannah Sparrows along 46 transmission line study sites in Winnipeg, Manitoba, Canada in 2008 ( $\mathrm{n}=138$ surveys), assuming a uniform detection probability with increasing distance of birds from the transect line and effects of Julian date, time of morning and observer experience on availability for detection.

\begin{tabular}{lrrrr}
\hline Density Parameter & Estimate & SE (Estimate) & $95 \%$ C.I. (Lower) & $95 \%$ C.I. (Upper) \\
Intercept & 1.43 & 0.25 & 0.93 & 1.92 \\
Wooded Land Within 100 & & & & \\
$\mathrm{m}$ & -0.03 & 0.02 & -0.05 & -0.02 \\
& & & & \\
Availability Parameter & Estimate & SE (Estimate) & $95 \%$ C.I. (Lower) & $95 \%$ C.I. (Upper) \\
Intercept & -9.39 & -1.93 & -5.61 & -13.18 \\
Julian & 0.06 & 0.01 & 0.03 & 0.08 \\
Time2 & 0.03 & 0.31 & -0.57 & 0.64 \\
Time3 & -0.90 & -0.33 & -0.25 & -1.55 \\
Time4 & -0.24 & -0.28 & 0.31 & -0.79 \\
Time5 & -0.60 & -0.34 & 0.07 & -1.28 \\
Obs (YW vs. LL) & -0.63 & -0.22 & -0.19 & -1.06 \\
\hline
\end{tabular}

Freeman-Tukey $\mathrm{X}^{2}=151$, mean(original-bootstrapped statistic) $=-55.2$, S.E. $=7.68, \mathrm{P}>0.998$. 
Table A2.L. Final hierarchical distance-sampling model $\left(\mathrm{AIC}_{\mathrm{c}}=790.16, \Delta \mathrm{AIC}_{\mathrm{c}}=0.00, \mathrm{AIC}\right.$ weight=0.87) for Savannah Sparrows along 44 transmission line study sites in Winnipeg, Manitoba, Canada in 2009 ( $\mathrm{n}=132$ surveys), assuming a uniform detection probability with increasing distance of birds from the transect line and effects of Julian date and time of morning on availability for detection.

\begin{tabular}{lrrrr}
\hline Density Parameter & Estimate & SE (Estimate) & $95 \%$ C.I. (Lower) & 95\% C.I. (Upper) \\
Intercept & 1.43 & 0.31 & 0.82 & 2.03 \\
Mowing frequency & 0.01 & 0.12 & -0.22 & 0.24 \\
Mowing frequency2 & 0.67 & 0.26 & 0.16 & 1.18 \\
Hayed (yes=1) & 1.06 & 0.27 & 0.53 & 1.59 \\
Urban Land Within 100 m & -0.03 & 0.01 & -0.05 & -0.02 \\
Grassland Within 100 m & 0.001 & 0.003 & -0.01 & 0.01 \\
Wooded Land Within 100 & & & & \\
m & -0.03 & 0.01 & -0.04 & -0.02 \\
& & & & \\
Availability Parameter & Estimate & SE (Estimate) & $95 \%$ C.I. (Lower) & $95 \%$ C.I. (Upper) \\
Intercept & -2.501 & 1.10 & -4.66 & -0.34 \\
Julian & 0.02 & 0.01 & 0.00 & 0.03 \\
Time2 & -0.19 & 0.26 & -0.70 & 0.32 \\
Time3 & -0.09 & 0.26 & -0.61 & 0.43 \\
Time4 & -0.82 & 0.27 & -1.35 & -0.29 \\
Time5 & -1.02 & 0.52 & -2.05 & 0.01 \\
\hline Freenan-Th
\end{tabular}

Freeman-Tukey $\mathrm{X}^{2}=235$, mean (original-bootstrapped statistic) $=18.4$, S.E. $=8.28, \mathrm{P}=0.016$. 
Table A3.A. Second-highest-ranking multi-season occupancy model $\left(\mathrm{AIC}_{\mathrm{c}}=337.90\right.$, $\triangle \mathrm{AIC}_{\mathrm{c}}=0.00$, AIC weight=0.12) for Clay-coloured Sparrows along 47 transmission line study sites in Winnipeg, Manitoba, Canada in 2008-2009 ( $\mathrm{n}=276$ surveys), assuming no effect of mowing on probability of colonization or extinction, and effects of Julian date and time of morning but not observer experience on probability of detection given presence at sites.

\begin{tabular}{|c|c|c|c|c|}
\hline Initial Occupancy Parameter & Estimate & $\begin{array}{l}\text { SE } \\
\text { (Estimate) }\end{array}$ & $\begin{array}{l}\text { 95\% C.I. } \\
\text { (Lower) }\end{array}$ & $\begin{array}{l}\text { 95\% C.I. } \\
\text { (Upper) }\end{array}$ \\
\hline Intercept & 0.94 & 0.90 & -0.82 & 2.70 \\
\hline Wooded Land Within $100 \mathrm{~m}$ & -0.04 & 0.02 & -0.08 & -0.00 \\
\hline Grass Cover & 0.19 & 0.13 & -0.06 & 0.44 \\
\hline $\begin{array}{l}\text { Colonization Probability } \\
\text { Parameter }\end{array}$ & Estimate & $\begin{array}{l}\text { SE } \\
\text { (Estimate) }\end{array}$ & $\begin{array}{l}\text { 95\% C.I. } \\
\text { (Lower) }\end{array}$ & $\begin{array}{l}\text { 95\% C.I. } \\
\text { (Upper) }\end{array}$ \\
\hline Intercept & -0.46 & 0.74 & -1.91 & 0.99 \\
\hline Extinction Probability Parameter & Estimate & $\begin{array}{l}\text { SE } \\
\text { (Estimate) }\end{array}$ & $\begin{array}{l}\text { 95\% C.I. } \\
\text { (Lower) }\end{array}$ & $\begin{array}{l}\text { 95\% C.I. } \\
\text { (Upper) }\end{array}$ \\
\hline Intercept & -3.19 & 1.07 & -5.29 & -1.09 \\
\hline Detection Probability Parameter & Estimate & $\begin{array}{l}\text { SE } \\
\text { (Estimate) }\end{array}$ & $\begin{array}{l}\text { 95\% C.I. } \\
\text { (Lower) }\end{array}$ & $\begin{array}{l}\text { 95\% C.I. } \\
\text { (Upper) }\end{array}$ \\
\hline Intercept & -4.20 & -2.30 & 0.30 & -8.70 \\
\hline Julian & 0.03 & 0.01 & 0.01 & 0.06 \\
\hline Time2 & -0.07 & -0.52 & 0.95 & -1.09 \\
\hline Time3 & -1.26 & -0.50 & -0.28 & -2.24 \\
\hline Time4 & -0.40 & -0.53 & 0.65 & -1.44 \\
\hline Time5 & -1.08 & -0.59 & 0.09 & -2.25 \\
\hline
\end{tabular}

Table A3.B. Third-highest-ranking multi-season occupancy model $\left(\mathrm{AIC}_{\mathrm{c}}=338.88, \Delta \mathrm{AIC}_{\mathrm{c}}=0.00\right.$, AIC weight $=0.08$ ) for Clay-coloured Sparrows along 47 transmission line study sites in Winnipeg, Manitoba, Canada in 2008-2009 ( $\mathrm{n}=276$ surveys), assuming no effect of mowing on probability of colonization or extinction, and effects of Julian date and time of morning but not observer experience on probability of detection given presence at sites.

\begin{tabular}{|c|c|c|c|c|c|}
\hline Initial Occupancy Parameter & Estimate & $\begin{array}{l}\text { SE } \\
\text { (Estimate) }\end{array}$ & $\begin{array}{l}\text { 95\% C.I. } \\
\text { (Lower) }\end{array}$ & $\begin{array}{l}\text { 95\% C.I. } \\
\text { (Upper) }\end{array}$ & \\
\hline Intercept & 2.13 & 0.68 & 0.79 & & 3.47 \\
\hline Wooded Land Within $100 \mathrm{~m}$ & -0.03 & 0.02 & -0.0623 & & -0.00 \\
\hline $\begin{array}{l}\text { Colonization Probability } \\
\text { Parameter }\end{array}$ & Estimate & $\begin{array}{l}\text { SE } \\
\text { (Estimate) }\end{array}$ & $\begin{array}{l}\text { 95\% C.I. } \\
\text { (Lower) }\end{array}$ & $\begin{array}{l}\text { 95\% C.I. } \\
\text { (Upper) }\end{array}$ & \\
\hline Intercept & -0.59 & 0.85 & -2.26 & & 1.08 \\
\hline
\end{tabular}




\begin{tabular}{|c|c|c|c|c|c|}
\hline Extinction Probability Parameter & Estimate & $\begin{array}{l}\text { SE } \\
\text { (Estimate) }\end{array}$ & $\begin{array}{l}\text { 95\% C.I. } \\
\text { (Lower) }\end{array}$ & $\begin{array}{l}\text { 95\% C.I. } \\
\text { (Upper) }\end{array}$ & \\
\hline Intercept & -3.16 & 1.06 & -5.24 & & -1.08 \\
\hline Detection Probability Parameter & Estimate & $\begin{array}{l}\text { SE } \\
\text { (Estimate) }\end{array}$ & $\begin{array}{l}\text { 95\% C.I. } \\
\text { (Lower) }\end{array}$ & $\begin{array}{l}\text { 95\% C.I. } \\
\text { (Upper) }\end{array}$ & \\
\hline Intercept & -4.92 & 2.34 & -9.50 & & -0.34 \\
\hline Julian & 0.04 & 0.01 & 0.01 & & 0.07 \\
\hline Time2 & -0.02 & 0.53 & -1.06 & & 1.02 \\
\hline Time3 & -1.26 & 0.51 & -2.26 & & -0.27 \\
\hline Time4 & -0.46 & 0.54 & -1.52 & & 0.59 \\
\hline Time5 & -1.06 & 0.60 & -2.24 & & 0.12 \\
\hline
\end{tabular}


Table A3.C. Second-highest-ranking multi-season occupancy model $\left(\mathrm{AIC}_{\mathrm{c}}=149.63\right.$, $\Delta \mathrm{AIC}_{\mathrm{c}}=2.13$, AIC weight $=0.10$ ) for Le Conte's Sparrows along 47 transmission line study sites in Winnipeg, Manitoba, Canada in 2008-2009 ( $\mathrm{n}=276$ surveys), assuming no effect of mowing on probability of colonization or extinction, and no effects of Julian date, time of morning or observer experience on probability of detection given presence at sites.

\begin{tabular}{|c|c|c|c|c|c|}
\hline Initial Occupancy Parameter & Estimate & $\begin{array}{l}\text { SE } \\
\text { (Estimate) }\end{array}$ & $\begin{array}{l}\text { 95\% C.I. } \\
\text { (Lower) }\end{array}$ & $\begin{array}{l}\text { 95\% C.I. } \\
\text { (Upper) }\end{array}$ & \\
\hline Intercept & -0.90 & 0.86 & -2.58 & & 0.78 \\
\hline Urban Land Within $100 \mathrm{~m}$ & -0.14 & 0.11 & -0.35 & & 0.07 \\
\hline $\begin{array}{l}\text { Colonization Probability } \\
\text { Parameter }\end{array}$ & Estimate & $\begin{array}{l}\text { SE } \\
\text { (Estimate) }\end{array}$ & $\begin{array}{l}\text { 95\% C.I. } \\
\text { (Lower) }\end{array}$ & $\begin{array}{l}\text { 95\% C.I. } \\
\text { (Upper) }\end{array}$ & \\
\hline Intercept & -1.01 & 0.42 & -1.84 & & -0.18 \\
\hline $\begin{array}{l}\text { Extinction Probability } \\
\text { Parameter }\end{array}$ & Estimate & $\begin{array}{l}\text { SE } \\
\text { (Estimate) }\end{array}$ & $\begin{array}{l}\text { 95\% C.I. } \\
\text { (Lower) }\end{array}$ & $\begin{array}{l}\text { 95\% C.I. } \\
\text { (Upper) }\end{array}$ & \\
\hline Intercept & -2.06 & 2.52 & -7.00 & & 2.88 \\
\hline $\begin{array}{l}\text { Detection Probability } \\
\text { Parameter }\end{array}$ & Estimate & $\begin{array}{l}\text { SE } \\
\text { (Estimate) }\end{array}$ & $\begin{array}{l}\text { 95\% C.I. } \\
\text { (Lower) }\end{array}$ & $\begin{array}{l}\text { 95\% C.I. } \\
\text { (Upper) }\end{array}$ & \\
\hline Intercept & -0.06 & 0.36 & -0.77 & & 0.65 \\
\hline
\end{tabular}

Table A3.D. Third-highest-ranking multi-season occupancy model $\left(\mathrm{AIC}_{\mathrm{c}}=150.14, \Delta \mathrm{AIC}_{\mathrm{c}}=2.64\right.$, AIC weight $=0.08$ ) for Le Conte's Sparrows along 47 transmission line study sites in Winnipeg, Manitoba, Canada in 2008-2009 ( $n=276$ surveys), assuming no effect of mowing on probability of colonization or extinction, and no effects of Julian date, time of morning or observer experience on probability of detection given presence at sites.

\begin{tabular}{|c|c|c|c|c|}
\hline Initial Occupancy Parameter & Estimate & $\begin{array}{l}\text { SE } \\
\text { (Estimate) }\end{array}$ & $\begin{array}{l}\text { 95\% C.I. } \\
\text { (Lower) }\end{array}$ & $\begin{array}{l}\text { 95\% C.I. } \\
\text { (Upper) }\end{array}$ \\
\hline Intercept & -1.89 & 1.31 & -4.45 & 0.67 \\
\hline Urban Land Within $100 \mathrm{~m}$ & -0.10 & 0.12 & -0.34 & 0.13 \\
\hline Mowing frequency & -1.32 & 1.18 & -3.64 & 1.00 \\
\hline $\begin{array}{l}\text { Colonization Probability } \\
\text { Parameter }\end{array}$ & Estimate & $\begin{array}{l}\text { SE } \\
\text { (Estimate) }\end{array}$ & $\begin{array}{l}\text { 95\% C.I. } \\
\text { (Lower) }\end{array}$ & $\begin{array}{l}\text { 95\% C.I. } \\
\text { (Upper) }\end{array}$ \\
\hline Intercept & -0.99 & 0.41 & -1.79 & -0.20 \\
\hline Extinction Probability Parameter & Estimate & $\begin{array}{l}\text { SE } \\
\text { (Estimate) }\end{array}$ & $\begin{array}{l}\text { 95\% C.I. } \\
\text { (Lower) }\end{array}$ & $\begin{array}{l}\text { 95\% C.I. } \\
\text { (Upper) }\end{array}$ \\
\hline Intercept & -1.89 & 2.23 & -6.260 & 2.48 \\
\hline Detection Probability Parameter & Estimate & SE & 95\% C.I. & 95\% C.I. \\
\hline
\end{tabular}




\begin{tabular}{lrrrrr}
\hline & & (Estimate) & (Lower) & \multicolumn{2}{c}{ (Upper) } \\
Intercept & -0.03 & 0.35 & -0.72 & 0.66 \\
\hline
\end{tabular}

Table A3.E. Second-highest-ranking multi-season occupancy model $\left(\mathrm{AIC}_{\mathrm{c}}=257.51\right.$, $\Delta \mathrm{AIC}_{\mathrm{c}}=1.61$, AIC weight $\left.=0.15\right)$ for Western Meadowlarks along 47 transmission line study sites in Winnipeg, Manitoba, Canada in 2008-2009 ( $n=276$ surveys), assuming no effect of mowing on probability of colonization or extinction, and no effects of Julian date, time of morning or observer experience on probability of detection given presence at sites.

\begin{tabular}{|c|c|c|c|c|}
\hline Initial Occupancy Parameter & Estimate & $\begin{array}{l}\text { SE } \\
\text { (Estimate) }\end{array}$ & $\begin{array}{l}\text { 95\% C.I. } \\
\text { (Lower) }\end{array}$ & $\begin{array}{l}\text { 95\% C.I. } \\
\text { (Upper) }\end{array}$ \\
\hline Intercept & -6.88 & 4.33 & -15.36 & 1.61 \\
\hline Urban Land Within $100 \mathrm{~m}$ & -0.03 & 0.03 & -0.09 & 0.03 \\
\hline Grassland Within 100 m & 0.08 & 0.03 & 0.02 & 0.14 \\
\hline Woodland Within $100 \mathrm{~m}$ & -0.06 & 0.03 & -0.12 & -0.01 \\
\hline Litter Cover & 0.07 & 0.05 & -0.02 & 0.17 \\
\hline $\begin{array}{l}\text { Colonization Probability } \\
\text { Parameter }\end{array}$ & Estimate & $\begin{array}{l}\text { SE } \\
\text { (Estimate) }\end{array}$ & $\begin{array}{l}\text { 95\% C.I. } \\
\text { (Lower) }\end{array}$ & $\begin{array}{l}\text { 95\% C.I. } \\
\text { (Upper) }\end{array}$ \\
\hline Intercept & -9.49 & 45.00 & -97.69 & 78.71 \\
\hline Extinction Probability Parameter & Estimate & $\begin{array}{l}\text { SE } \\
\text { (Estimate) }\end{array}$ & $\begin{array}{l}\text { 95\% C.I. } \\
\text { (Lower) }\end{array}$ & $\begin{array}{l}\text { 95\% C.I. } \\
\text { (Upper) }\end{array}$ \\
\hline Intercept & -6.70 & 31.20 & -67.85 & 54.45 \\
\hline Detection Probability Parameter & Estimate & $\begin{array}{l}\text { SE } \\
\text { (Estimate) }\end{array}$ & $\begin{array}{l}\text { 95\% C.I. } \\
\text { (Lower) }\end{array}$ & $\begin{array}{l}\text { 95\% C.I. } \\
\text { (Upper) }\end{array}$ \\
\hline Intercept & -0.34 & 0.18 & -0.70 & 0.02 \\
\hline
\end{tabular}

Table A3.F. Third-highest-ranking multi-season occupancy model $\left(\mathrm{AIC}_{\mathrm{c}}=257.99, \Delta \mathrm{AIC}_{\mathrm{c}}=2.09\right.$, AIC weight=0.12) for Western Meadowlarks along 47 transmission line study sites in Winnipeg, Manitoba, Canada in 2008-2009 ( $n=276$ surveys), assuming no effect of mowing on probability of colonization or extinction, and no effects of Julian date, time of morning or observer experience on probability of detection given presence at sites.

\begin{tabular}{|c|c|c|c|c|}
\hline Initial Occupancy Parameter & Estimate & $\begin{array}{l}\text { SE } \\
\text { (Estimate) }\end{array}$ & $\begin{array}{l}\text { 95\% C.I. } \\
\text { (Lower) }\end{array}$ & $\begin{array}{l}\text { 95\% C.I. } \\
\text { (Upper) }\end{array}$ \\
\hline Intercept & -1.36 & 1.40 & -4.10 & 1.38 \\
\hline Urban Land Within $100 \mathrm{~m}$ & -0.05 & 0.04 & -0.12 & 0.02 \\
\hline Grassland Within 100 m & 0.08 & 0.03 & 0.02 & 0.14 \\
\hline Woodland Within $100 \mathrm{~m}$ & -0.06 & 0.03 & -0.12 & -0.00 \\
\hline
\end{tabular}




\begin{tabular}{|c|c|c|c|c|}
\hline $\begin{array}{l}\text { Colonization Probability } \\
\text { Parameter }\end{array}$ & Estimate & $\begin{array}{l}\text { SE } \\
\text { (Estimate) }\end{array}$ & $\begin{array}{l}\text { 95\% C.I. } \\
\text { (Lower) }\end{array}$ & $\begin{array}{l}\text { 95\% C.I. } \\
\text { (Upper) }\end{array}$ \\
\hline Intercept & -1.90 & 0.93 & -3.71 & -0.09 \\
\hline Extinction Probability Parameter & Estimate & $\begin{array}{l}\text { SE } \\
\text { (Estimate) }\end{array}$ & $\begin{array}{l}\text { 95\% C.I. } \\
\text { (Lower) }\end{array}$ & $\begin{array}{l}\text { 95\% C.I. } \\
\text { (Upper) }\end{array}$ \\
\hline Intercept & -3.43 & 3.86 & -11.00 & 4.14 \\
\hline Detection Probability Parameter & Estimate & $\begin{array}{l}\text { SE } \\
\text { (Estimate) }\end{array}$ & $\begin{array}{l}\text { 95\% C.I. } \\
\text { (Lower) }\end{array}$ & $\begin{array}{l}\text { 95\% C.I. } \\
\text { (Upper) }\end{array}$ \\
\hline Intercept & -0.21 & 0.21 & -0.63 & 0.21 \\
\hline
\end{tabular}

